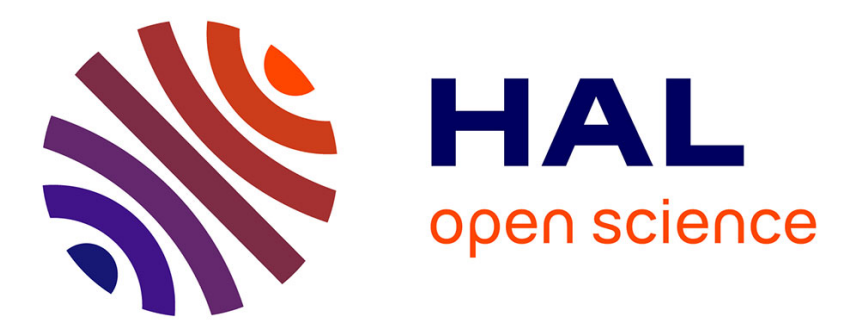

\title{
Modulation of Bcl-2-related protein expression in pancreatic beta cells by pro-inflammatory cytokines and its dependence on the antioxidative defense status
}

\author{
Ilir Mehmeti, Sigurd Lenzen, Stephan Lortz
}

\section{- To cite this version:}

Ilir Mehmeti, Sigurd Lenzen, Stephan Lortz. Modulation of Bcl-2-related protein expression in pancreatic beta cells by pro-inflammatory cytokines and its dependence on the antioxidative defense status. Molecular and Cellular Endocrinology, 2010, 332 (1-2), pp.88. 10.1016/j.mce.2010.09.017. hal-00654967

\section{HAL Id: hal-00654967 \\ https://hal.science/hal-00654967}

Submitted on 24 Dec 2011

HAL is a multi-disciplinary open access archive for the deposit and dissemination of scientific research documents, whether they are published or not. The documents may come from teaching and research institutions in France or abroad, or from public or private research centers.
L'archive ouverte pluridisciplinaire HAL, est destinée au dépôt et à la diffusion de documents scientifiques de niveau recherche, publiés ou non, émanant des établissements d'enseignement et de recherche français ou étrangers, des laboratoires publics ou privés. 


\section{Accepted Manuscript}

Title: Modulation of Bcl-2-related protein expression in pancreatic beta cells by pro-inflammatory cytokines and its dependence on the antioxidative defense status

Authors: Ilir Mehmeti, Sigurd Lenzen, Stephan Lortz

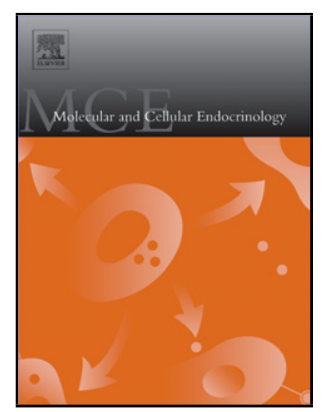

PII:

S0303-7207(10)00488-0

DOI: doi:10.1016/j.mce.2010.09.017

Reference: MCE 7648

To appear in: $\quad$ Molecular and Cellular Endocrinology

Received date: $\quad 3-5-2010$

Revised date: $\quad 3-9-2010$

Accepted date: $\quad$ 28-9-2010

Please cite this article as: Mehmeti, I., Lenzen, S., Lortz, S., Modulation of Bcl-2related protein expression in pancreatic beta cells by pro-inflammatory cytokines and its dependence on the antioxidative defense status, Molecular and Cellular Endocrinology (2010), doi:10.1016/j.mce.2010.09.017

This is a PDF file of an unedited manuscript that has been accepted for publication. As a service to our customers we are providing this early version of the manuscript. The manuscript will undergo copyediting, typesetting, and review of the resulting proof before it is published in its final form. Please note that during the production process errors may be discovered which could affect the content, and all legal disclaimers that apply to the journal pertain. 
Modulation of Bcl-2-related protein expression in pancreatic beta cells by pro-inflammatory cytokines and its dependence on the antioxidative defense status

\subsubsection{Ilir Mehmeti, Sigurd Lenzen*, Stephan Lortz} Institute of Clinical Biochemistry, Hannover Medical School, 30623 Hannover, Germany.

*Address correspondence and reprint requests to:

Prof. Sigurd Lenzen

Institute of Clinical Biochemistry

Hannover Medical School

30623 Hannover

Germany

Telephone: $\quad+49 / 511 / 5326525$

Fax: $\quad+49 / 511 / 5323584$

lenzen.sigurd@mh-hannover.de

Abbreviated title: Regulation of Bcl-2 proteins by ROS and cytokines 


\begin{abstract}
Pro-inflammatory cytokines are key mediators in the selective and progressive destruction of insulinproducing beta cells during type 1 diabetes development. However, the mechanisms of cytokineinduced beta cell apoptosis are not fully understood.

This study demonstrates that pro-inflammatory cytokines strongly modified the expression of the antiapoptotic protein $\mathrm{Bcl}-2$ and the pro-apoptotic $\mathrm{BH} 3$-only proteins Bad, Bim, and Bid in primary rat islets and insulin-producing RINm5F cells. Overexpression of mitochondrially located catalase (MitoCatalase) specifically increased basal Bcl-2 and decreased basal Bax expression, suppressed cytokine-mediated reduction of $\mathrm{Bcl}-2$, and thereby prevented the release of cytochrome $\mathrm{c}$, Smac/DIABLO and the activation of caspase- 9 and -3 . Thus, cytokine-mediated decrease of Bcl-2 expression and the sequentially changed $\mathrm{Bax} / \mathrm{Bcl}-2$ ratio are responsible for the release of proapoptotic mitochondrial factors, activation of caspase-9, and ultimately caspase-3.

These results indicate that activation of the intrinsic/mitochondrial apoptosis pathway is essential for cytokine-induced beta cell death and the mitochondrial generation of reactive oxygen species, in particular mitochondrial hydrogen peroxide, differentially regulates the Bax/Bcl-2 ratio.
\end{abstract}

\title{
Keywords
}

Bcl-2 proteins; pancreatic beta cells; antioxidative defense status; pro-inflammatory cytokines; apoptosis 
I. Mehmeti et al.

\begin{abstract}
Abbreviations
Apaf-1, apoptosis-protease activating factor-1; $\mathrm{BH}, \mathrm{Bcl}-2$ homology domain; CREB, cAMP response element-binding protein; $\mathrm{Ct}$, cycle threshold; GPX1, glutathione peroxidise-1; $\mathrm{H}_{2} \mathrm{O}_{2}$, hydrogen peroxide; IAP, inhibitor of apoptosis protein; IFN- $\gamma$, interferon- $\gamma$; IL-1 $\beta$, interleukin-1 $\beta$; MAPK, mitogen-activated protein kinase; NFKB, nuclear factor kappa B; PI-3K, phosphatidylinositol 3kinase; ROS, reactive oxygen species; Smac/DIABLO, second mitochondria-derived activator of caspase/direct inhibitor of apoptosis-binding protein with low pI; T1DM, Type 1 Diabetes mellitus; TNF- $\alpha$, tumor necrosis factor- $\alpha$; XIAP, X-linked inhibitor of apoptosis protein.
\end{abstract}




\section{Mehmeti et al.}

\section{Introduction}

Pancreatic beta cell apoptosis plays a crucial role in the pathogenesis of Type 1 Diabetes mellitus (T1DM) (Atkinson, 2005; Eizirik and Mandrup-Poulsen, 2001; Kim and Lee, 2009). This process is initiated by two main pathways: the "extrinsic" or death receptor and the "intrinsic" or mitochondrial apoptosis pathway (Huerta et al., 2007; Millan and Huerta, 2009). The intrinsic death pathway involves loss of mitochondrial homeostasis, particularly of the outer mitochondrial membrane integrity, and subsequently the release of mitochondrial pro-apoptotic factors including cytochrome c. Once released, cytochrome c promotes the assembly of the so-called apoptosome, consisting of cytochrome c, apoptosis-protease activating factor-1 (Apaf-1), ATP/dATP, and pro-caspase-9. Upon formation of this complex, activated caspase-9 triggers the processing and activation of effector caspases, which ultimately culminates in apoptotic cell death (Danial and Korsmeyer, 2004; Kroemer et al., 2007; Susnow et al., 2009). Permeablization of the mitochondrial outer membrane and the consequent release of cytochrome $\mathrm{c}$ are tightly regulated by a group of proteins known as the Bcl-2 protein family (Adams and Cory, 1998). This family is composed of pro- and anti-apoptotic proteins that share up to four conserved regions known as Bcl-2 homology $(\mathrm{BH})$ domains. Anti-apoptotic members such as $\mathrm{Bcl}-2$ and $\mathrm{Bcl}-\mathrm{X}_{\mathrm{L}}$ contain all four subtypes of $\mathrm{BH}$ domains and promote cell survival by inhibiting the function of the pro-apoptotic Bcl-2 family members. The pro-apoptotic members can be further subdivided into two subfamilies: multidomain proteins (e.g. Bax and Bak), containing BH13, or the BH3-only proteins (e.g. Bad, Bim, Bid, Noxa, and Puma) that contain only the BH3 domain critical for the induction of apoptosis (Danial and Korsmeyer, 2004; Strasser, 2005). Although the precise mechanisms by which these proteins regulate cell death are not fully understood, it appears that the interaction and the ratio between anti- and pro-apoptotic Bcl-2 family proteins determine the fate of cells exposed to apoptotic stimuli (Adams and Cory, 1998; Wong and Puthalakath, 2008).

Studies with non-insulin-secreting cells suggested that reactive oxygen species (ROS), in particular hydrogen peroxide $\left(\mathrm{H}_{2} \mathrm{O}_{2}\right)$, decrease the expression of $\mathrm{Bcl}-2$ and increase that of proapoptotic proteins, e.g. Bax, thereby changing the $\mathrm{Bax} / \mathrm{Bcl}-2$ ratio which determines the susceptibility of cells to apoptosis (Korsmeyer et al., 1993; Oltvai et al., 1993; Raisova et al., 2001). In addition, the pro-inflammatory cytokines interleukin $1 \beta$ (IL-1 $\beta$ ), tumor necrosis factor $\alpha$ (TNF- $\alpha$ ), and interferon $\gamma$ 
I. Mehmeti et al.

(IFN- $\gamma$ ) down-regulated the expression of the anti-apoptotic protein Bcl-2 in pancreatic islets (Piro et al., 2001; Trincavelli et al., 2002; Van de Casteele et al., 2002); whereas, the overexpression of Bcl-2 in beta cells protected against cytokine-induced cell death (Barbu et al., 2002; Rabinovitch et al., 1999; Tran et al., 2003).Furthermore, inhibition of Bax mitochondrial translocation by the potential Bax suppressor protein V5 (also known as Ku70) resulted in a higher resistance against apoptotic stimuli in HEK293T and HeLa cells (Sawada et al., 2003) and also against cytokine-induced toxicity in human pancreatic beta cells (Grunnet et al., 2009)

The relation between ROS and the pro-inflammatory beta cell toxic cytokines IL-1 $\beta$, TNF- $\alpha$, and IFN- $\gamma$ in their influence on the expression of anti- $\left(\mathrm{Bcl}-2\right.$ and $\left.\mathrm{Bcl}-\mathrm{X}_{\mathrm{L}}\right)$ and pro-apoptotic (Bax, Bad, Bim, and Bid) proteins is still unknown. Therefore, the expression pattern of these proteins and its relation to the toxicity of pro-inflammatory cytokines, as well as its dependence on the antioxidative defense status, was analyzed in primary rat islets and in insulin-producing RINm5F cells overexpressing antioxidative enzymes. 
I. Mehmeti et al.

\section{Materials and Methods \\ 2.1. Tissue culture of RINm5F cells}

Insulin-producing RINm5F tissue culture cells were cultured as described earlier in RPMI1640 medium supplemented with $10 \mathrm{mM}$ glucose, $10 \%(\mathrm{v} / \mathrm{v})$ fetal calf serum (FCS), penicillin, and streptomycin in a humidified atmosphere at $37{ }^{\circ} \mathrm{C}$ and $5 \% \mathrm{CO}_{2}$ (Lortz et al., 2000). The RINm5F cells overexpressing catalase in the cytosol (CytoCatalase) or in mitochondria (MitoCatalase) were generated as described before in detail (Gurgul et al., 2004). Briefly, for overexpression of catalase in cytosol or mitochondria, human catalase cDNA was subcloned into the pcDNA3 (cytosolic overexpression) or $\mathrm{pCMV} / \mathrm{myc} / \mathrm{mito}$-plasmid (mitochondrial overexpression) and the stabile clones were selected through resistance against G418. Cells transfected with the $\mathrm{pCMV} / \mathrm{myc} / \mathrm{mito}$ vector lacking insert were used as control cells. Expression of antioxidative enzymes in the cells was analyzed by catalase enzyme activity measurement (Gurgul et al., 2004). The catalase enzyme activities were as follows in the control cells with an empty vector and in cells overexpressing CytoCatalase or MitoCatalase, respectively (in U/mg total protein): control cells, $31 \pm 0.2$; CytoCatalase, $346 \pm 2.8 ;$ MitoCatalase, $594 \pm 18.8$.

\subsection{Rat islet isolation}

Pancreatic islets were isolated from 250-300 g adult male Lewis rats by collagenase digestion, separated by Ficoll gradient, and handpicked under a stereo microscope (Tiedge et al., 1997). Isolated islets were cultured overnight in RPMI-1640 medium supplemented with $5 \mathrm{mM}$ glucose, $10 \%$ FCS, penicillin, and streptomycin at $37{ }^{\circ} \mathrm{C}$ in a humidified atmosphere of $5 \% \mathrm{CO}_{2}$.

\subsection{Exposure to cytokines}

Control and transfected RINm5F cells were seeded at different concentrations depending on the further experimentation and allowed to attach for a period of $24 \mathrm{~h}$. For islet incubations, 100-150 uniformly sized handpicked, precultured islets were used. Cells were exposed to $600 \mathrm{U} / \mathrm{ml}$ human IL-

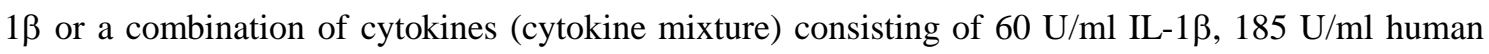

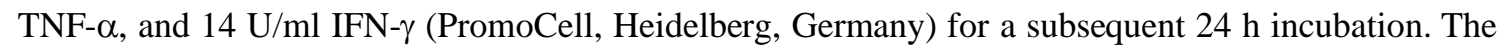
indicated cytokine concentrations were selected based upon the results of previous studies (Lortz et al., 
I. Mehmeti et al.

2000; Nerup et al., 1994; Nielsen et al., 2004). IL-1 $\beta$ is the most potent beta cell toxic cytokine and strongly contributes to beta cell death by activation of the NFkB and MAPK transduction pathways. TNF- $\alpha$ and IFN- $\gamma$ alone are significantly weaker in this respect; however in synergy with IL-1 $\beta$ they potentiate its deleterious action through induction of additional signaling pathways (Eizirik and Mandrup-Poulsen, 2001). Therefore, the used cytokine mixture contained 10-fold less IL-1 $\beta$ than the IL-1 $\beta$ solution alone, in order to achieve a comparable toxicity (Souza et al., 2008).

\subsection{Real-time Quantitative RT-PCR}

Total RNA from insulin-producing RINm5F cells was isolated using the Chomczynski protocol, while the RNA from incubated islets was isolated with NucleoSpin RNA/Protein columns (Macherey-Nagel, Düren, Germany). RNA was quantified and analyzed by the Experion automated electrophoresis system (BioRad Laboratories, Hercules, CA, USA). For cDNA synthesis, random hexamers were used to prime the reaction of the RevertAid $\mathrm{H}^{-} \mathrm{M}-\mathrm{MuLV}$ reverse transcriptase (Fermentas, St. Leon-Rot, Germany). QuantiTect SYBR Green technology (Qiagen, Hilden, Germany), which uses a fluorescent dye that binds only double-stranded DNA, was employed. The reactions were performed using the DNA Engine Opticon Sequence Detection System (BioRad Laboratories, Hercules, CA, USA). Samples were first denatured at $94{ }^{\circ} \mathrm{C}$ for 3 min followed by 40 PCR cycles comprised of a melting step at $94{ }^{\circ} \mathrm{C}$ for $30 \mathrm{~s}$, an annealing step at $60{ }^{\circ} \mathrm{C}$ for $30 \mathrm{~s}$, and an extension step at $72{ }^{\circ} \mathrm{C}$ for $30 \mathrm{~s}$. Primers for qRT-PCR were used at an annealing temperature of $60{ }^{\circ} \mathrm{C}$ and gave an amplicon of 79-216 base pairs (Table 1). The optimal parameters for the PCR reactions were empirically defined and the purity and specificity of the amplified PCR product in each experiment was verified by melting curves. All analyzed transcripts showed Ct-values, which were at least $10 \mathrm{Ct}$-values lower than the blank values. Each PCR amplification was performed in triplicate. Data are expressed as relative gene expression after normalization to the beta actin housekeeping gene using the Qgene96 and LineRegPCR software.

\subsection{Tissue fractionation}

Trypsinized RINm5F cells were collected by centrifugation at $700 \mathrm{~g}$ for $5 \mathrm{~min}$, washed twice 


\section{Mehmeti et al.}

with ice-cold PBS, and centrifuged at $700 \mathrm{~g}$ for $5 \mathrm{~min}$ at $4{ }^{\circ} \mathrm{C}$. The cell pellets were resuspended in $500 \mu \mathrm{l}$ of ice-cold $\mathrm{H}$-medium (70 mM sucrose, $210 \mathrm{mM}$ mannitol, $20 \mathrm{mM}$ HEPES, $150 \mathrm{mM} \mathrm{KCl}$, and 0.5 mM EGTA, pH 7.4) supplemented with Complete protease inhibitor cocktail (Roche Diagnostics, Manheim, Germany), and homogenized on ice with 25-30 strokes in a Potter-Elvehjem homogenizer. Fractions were obtained through differential centrifugation. Cell homogenates were centrifuged at 500 $\mathrm{g}$ for $10 \mathrm{~min}$ at $4{ }^{\circ} \mathrm{C}$ to discard nuclei and unbroken cells. The mitochondrial fraction was obtained through centrifugation for $10 \mathrm{~min}$ at $10000 \mathrm{~g}$ at $4{ }^{\circ} \mathrm{C}$. The supernatant was then centrifuged for another $60 \mathrm{~min}$ at $100000 \mathrm{~g}$ at $4{ }^{\circ} \mathrm{C}$, to separate the microsomal and the cytoplasmic fractions (Lenzen et al., 1985).

\subsection{Western blot analyses}

RINm5F whole cell extracts (for detection of Bcl-2 family members) or subcellular fractions (for cytochrome $\mathrm{c}$ and Smac/DIABLO detection) were sonified in ice-cold PBS on ice for $15 \mathrm{~s}$ at $60 \mathrm{~W}$ with a Braun-Sonic 125 sonifier. Protein content was determined by the BCA assay (Pierce, Rockford, IL, USA) or the Bradford assay. Whole islet cell proteins were obtained through a combined RNA/protein isolation procedure (NucleoSpin RNA/Protein columns, Macherey-Nagel, Düren, Germany) and prepared for Western blot analyses in accordance with the manufacturer's protocol. RINm5F cell protein $(20-30 \mu \mathrm{g})$ or the protein fraction of $100-150$ islets per lane were separated by a 12.5\% SDS-PAGE and transferred to polyvinylidene fluoride membranes. Nonspecific binding sites of the membranes were blocked with 5\% non-fat dry milk for either $1 \mathrm{~h}$ at room temperature or overnight at $4{ }^{\circ} \mathrm{C}$. Then, the membranes were incubated with specific primary antibodies for either $4 \mathrm{~h}$ at room temperature or overnight at $4{ }^{\circ} \mathrm{C}$. The following antibodies were used: Bcl-2 (sc-7382, diluted 1:500), Bax (sc-7480, 1:250), Smac/DIABLO (sc-12683, 1:250), cytochrome c (sc-7159, 1:250), and actin (sc-1615, 1:250) (Santa Cruz Biotechnology, Santa Cruz, CA, USA); Bcl-X $\mathrm{L}_{\mathrm{L}}(610211,1: 1000)$ (BD Biosciences, Franklin Lakes, NJ, USA); phospho-Ser ${ }^{136}$ Bad, (44-524, 1:500) (Biosource, Camarillo, CA, USA); Bid (1:500), (R\&D Systems, Minneapolis, MN, USA); and Bim (ap-330, 1:1000) (Stressgen, Victoria, BC, Canada). The excess of primary antibody was removed by three washes with wash buffer (PBS, $0.1 \%$ Tween 20, 0.1\% BSA). Subsequently, the membranes were incubated with peroxidase-labeled secondary antibodies at a dilution of 1:20 000 at room temperature for $1 \mathrm{~h}$. The 


\section{Mehmeti et al.}

protein bands were visualized by chemiluminescence using the ECL detection system (Amersham Bioscience, Freiburg, Germany). The intensity of the bands was quantified with respect to $\beta$-actin bands through densitometry with the Gel-Pro Analyzer 6.0 program (Media Cybernetics, Silver Spring, MD, USA).

\subsection{Flow cytometric quantification of caspase-9 and caspase-3 activity}

Caspase-9 and -3 activities were determined with the CaspGLOW staining kits (Promocell, Heidelberg, Germany). Control and overexpressing RINm5F cells were seeded at a density of $1 \times 10^{6}$ cells per well and allowed to attach for a period of $24 \mathrm{~h}$ at $37{ }^{\circ} \mathrm{C}$ before incubation with the indicated cytokines. After $24 \mathrm{~h}$ exposure to IL-1 $\beta$ or the cytokine mixture, the cells were trypsinized and collected by centrifugation at $700 \mathrm{~g}$ for $5 \mathrm{~min}$. Cell pellets were resuspended in $1 \mathrm{ml}$ medium and 300 $\mu 1$ of each sample were transferred to Eppendorf tubes. According to the manufacturer's protocol, FITC-LEHD-FMK (caspase-9) or Red-DEVD-FMK (caspase-3) was added to these cells and incubated for $45 \mathrm{~min}$ at $37{ }^{\circ} \mathrm{C}$ followed by washing twice with wash buffer. The cells were resuspended in $1 \mathrm{ml}$ of washing buffer and 20000 cells of each sample were analyzed by flow cytometry (CyFlow ML, Partec, Münster, Germany) using the FL-1 channel (488 nm/527 nm) for caspase-9 or FL-2 channel (488 nm/575 nm) for caspase-3.

\subsection{Data analysis}

The data are expressed as means \pm SEM. Statistical analyses were performed by ANOVA followed by Dunnett's test for multiple comparisons using the Prism analysis program (Graphpad, San Diego, CA, USA). 
I. Mehmeti et al.

\section{Results \\ 3.1. Expression of Bcl-2-related proteins in primary rat islets and insulin-producing cells}

Mitochondrial integrity and stability are dependent upon the expression and interaction of proand anti-apoptotic Bcl-2 proteins. Therefore, the expression of anti- and pro-apoptotic Bcl-2 family members in primary rat islets and insulin-producing RINm5F tissue culture cells was characterized by qRT-PCR. Gene expression of the anti-apoptotic (Bcl-2 and Bcl- $\mathrm{X}_{\mathrm{L}}$ ) and pro-apoptotic (Bax, Bad, Bim, and Bid) Bcl-2 proteins could be detected in primary rat islets and RINm5F cells. The proapoptotic protein Bax showed the highest gene expression level of all investigated Bcl-2 proteins and its expression level was 5-fold higher in primary rat islets and 8.5 -fold higher in RINm5F cells, compared with the anti-apoptotic protein Bcl-2. Moreover, Bcl- $\mathrm{X}_{\mathrm{L}}$ and Bad revealed a 2-fold higher gene expression than Bcl-2 in primary islets and 4-fold higher in RINm5F cells; whereas the relative gene expression of the BH3-only proteins Bim and Bid was comparable with that of Bcl-2 (Fig. 1a and b). Overall, the expression pattern of all investigated Bcl-2-related proteins was comparable in primary rat islets and RINm5F cells.

\subsection{Effects of pro-inflammatory cytokines on the expression of Bcl-2-related proteins in primary} rat islets and insulin-producing cells

Exposure of primary islets and insulin producing cells to IL-1 $\beta$ alone resulted in alteration of multiple genes, cellular function impairment, and apoptosis. In combination with TNF- $\alpha$ and /or IFN- $\gamma$ these phenomena could be synergistically potentiated (Eizirik and Mandrup-Poulsen, 2001). To characterize the influence of these beta cell toxic cytokines on the gene expression pattern of Bcl-2 related proteins, primary rat islets and RINm5F cells were incubated with IL-1 $\beta$ alone or with a proinflammatory cytokine mixture consisting of IL-1 $\beta$, TNF- $\alpha$, and IFN- $\gamma$. A 24 h exposure of primary rat islets to IL-1 $\beta$ or the cytokine mixture caused a significant reduction of Bcl-2 $(P<0.001)$ and Bad (IL-1 $\beta$ : $P<0.05$; cytokine mixture: $P<0.01)$ gene expression. In contrast, the gene expression of Bcl$\mathrm{X}_{\mathrm{L}}(P<0.01)$ and Bid (IL-1 $\beta: P<0.01$; cytokine mixture: $\left.P<0.001\right)$ was significantly increased under the same treatment conditions, whereas that of Bim was only slightly but not significantly 


\section{Mehmeti et al.}

upregulated. The gene expression of Bax remained unchanged after cytokine treatment (Fig. 2a). The changes in expression patterns, induced by cytokines in primary rat islets, were also observed in RINm5F tissue culture cells (Fig. 2c). Again, expression of Bcl-2 was significantly reduced by IL-1 $\beta$ alone and the cytokine mixture $(P<0.001)$. The Bad gene expression was only marginally affected by exposure to IL-1 $\beta$ alone, while the cytokine mixture induced a significant $25 \%$ decrease of Bad $(P<$ 0.05). The $\mathrm{Bcl}-\mathrm{X}_{\mathrm{L}}$ gene expression was significantly increased by $38 \%$ only after cytokine mixture treatment $(P<0.01)$. However, in contrast to primary rat islets, the Bim gene expression in RINm5F culture cells was significantly induced by IL- $1 \beta$ and the cytokine mixture (IL- $1 \beta$ : $P<0.01$; cytokine mixture: $P<0.001$ ), whereas the Bid gene expression was similarly enhanced as observed in primary islets (IL-1 $\beta$ : $P<0.01$; cytokine mixture: $P<0.001$, Fig. 2 c). As in primary rat islets, the gene expression of Bax was not influenced by IL-1 $\beta$ or the cytokine mixture.

To verify the gene expression data obtained by qRT-PCR, Western blot analyses were performed. As shown in Fig. $2 \mathrm{~b}$ and d, the protein expression of all investigated Bcl-2-related proteins in rat islets and RINm5F cells showed a very high correlation with the gene expression data. Nevertheless, the observed cytokine-induced increase of $\mathrm{Bcl}-\mathrm{X}_{\mathrm{L}}$ gene expression in primary islets could not be verified on protein level, whereas the Bim protein expression was significantly induced after treatment with IL-1 $\beta$ alone or the cytokine mixture $(P<0.05)$. Since the BH3-only protein Bad remains under control conditions in an inactive phosphorylated state and is sequestered in the cytosol by a 14-3-3 molecule (Zha et al., 1996), we examined not only the total Bad protein expression, but also the cytokine-mediated dephosphorylation of $\mathrm{Bad}_{\text {at }} \mathrm{Ser}^{136}$. In rat islets and in RINm5F cells, IL$1 \beta$ alone and the cytokine mixture induced $\mathrm{Bad} \mathrm{Ser}^{136}$ dephosphorylation (Fig. $2 \mathrm{~b}$ and d), without affecting total Bad expression (data not shown).

Taken together, these findings demonstrate that pro-inflammatory cytokines modify the expression of most of the investigated Bcl-2-related proteins, indicating a complex regulation and a possible participation of these proteins in cytokine-induced beta cell toxicity, both in primary rat islets and in insulin-producing RINm5F cells. Among the investigated Bcl-2 proteins, Bcl-2, Bim, and Bid expression revealed the highest alterations in response to pro-inflammatory cytokines. 
I. Mehmeti et al.

\subsection{Effects of antioxidative enzymes on the expression of Bcl-2-related proteins in insulin-} producing cells

In beta cells and insulin-producing cell lines the $\mathrm{H}_{2} \mathrm{O}_{2}$ inactivating capacity in comparison to other tissues is extremely low (Lenzen et al., 1996; Tiedge et al., 1997). Catalase overexpression in insulin-producing RINm5F cells resulted in a higher resistance against different chemical ROS donors. However, stable overexpression of catalase in the mitochondrial compartment protected these cells more efficiently against cytokine-induced toxicity than the overexpression of catalase in the cytosolic compartment (Gurgul et al., 2004; Lortz et al., 2000). Therefore, these RINm5F cells stably overexpressing the $\mathrm{H}_{2} \mathrm{O}_{2}$ detoxifying enzyme catalase in the cytosol (CytoCatalase) or mitochondria (MitoCatalase) were used to examine the influence of antioxidative enzymes on the expression of Bcl-2-related proteins.

RINm5F cells overexpressing CytoCatalase showed significantly lower Bcl-2 gene expression $(P<0.01)$, whereas the expression level of Bax was only slightly increased (Bcl-2: $32 \%$ and Bax: $141 \%$ of the control cells). In accordance with this, protein expression analysis also revealed a significantly lower Bcl-2 $(P<0.001)$ and up-regulated Bax expression $(\mathrm{Bcl}-2: 10 \%$ and Bax: $135 \%$ of the control cells). Thus, the calculated Bax to Bcl-2 ratio of the CytoCatalase cells increased 4.4-fold at the mRNA level and 13.5-fold at the protein level, compared with control cells (Fig. 3a and b).

In contrast, Bcl-2 gene expression in MitoCatalase cells was significantly higher and that of Bax significantly lower than in control cells ( $P<0.05$, Bcl-2: 204\% and Bax: $48 \%$ of the control cells). Western blot analysis also revealed elevated Bcl-2 and significantly decreased $\mathrm{Bax}(P<0.05)$ protein levels (Bcl-2: 206\% and Bax: 46\% of the control cells, Fig. 3b). Based on this observation, the ratio of Bax to Bcl-2 decreased 4.3-fold at the mRNA level and 3.3-fold at the protein level, compared with control cells. The expression levels of Bcl- $\mathrm{X}_{\mathrm{L}}$, Bad, Bim, and Bid did not differ significantly between control cells and cells overexpressing CytoCatalase or MitoCatalase (data not shown). Therefore, only the expression of $\mathrm{Bcl}-2$ and $\mathrm{Bax}$ in response to cytokines was characterized in these catalase overexpressing RINm5F cells. 
I. Mehmeti et al.

\subsection{Effects of pro-inflammatory cytokines on the expression of Bcl-2 and Bax in insulin-producing cells overexpressing antioxidative enzymes}

Next, we examined the effects of pro-inflammatory cytokines on the expression of Bcl-2 and Bax in insulin-producing RINm5F cells stably overexpressing CytoCatalase or MitoCatalase. Control and CytoCatalase cells, incubated for $24 \mathrm{~h}$ with IL-1 $\beta$ alone or in combination with TNF- $\alpha$ and IFN- $\gamma$, resulted in a significant reduction of Bcl-2 gene expression (control cells: IL-1 $32 \%(P<0.001)$ and cytokine mixture 50\% $(P<0.001)$ of untreated cells; CytoCatalase cells: IL-1 $\beta 67 \%(P<0.01)$ and cytokine mixture 55\% ( $P<0.001)$ of untreated cells). On the other hand, MitoCatalase cells showed no significant reduction of Bcl-2 gene expression after cytokine treatment (Fig. 4a). These gene expression results were confirmed by Western blot analyses. As shown in Fig. 4b, Bcl-2 protein expression in control cells was reduced to a similar extent as the gene expression in response to cytokines (IL-1 $\beta$ : $59 \%$ and cytokine mixture: $51 \%$ of untreated cells, $P<0.001$ ). However, the reduction of Bcl-2 protein expression in cells overexpressing CytoCatalase was markedly greater after cytokine incubation (IL-1 $\beta$ : $28 \%$ and cytokine mixture: $23 \%$ of untreated cells, $P<0.001$ ); whereas, Bcl-2 protein expression remained unchanged in cells overexpressing MitoCatalase (IL-1 1 115\% and cytokine mixture $109 \%$ of untreated cells). Thus, MitoCatalase overexpression completely prevented cytokine-induced Bcl-2 down-regulation.

In contrast, Bax gene expression was not affected by cytokine treatment in control cells and cells overexpressing CytoCatalase or MitoCatalase (Fig. 5a). At the protein level, similar expression profiles of Bax were observed in control and CytoCatalase cells. Conversely, Bax protein expression was surprisingly decreased in CytoCatalase cells after incubation with the cytokine mixture (48\% of untreated cells, $P<0.01$, Fig. 5b). In MitoCatalase cells Bax protein expression was only moderately but not significantly increased after cytokine treatment (IL-1 $\beta \quad 128 \%$ and cytokine mixture $151 \%$ of untreated cells, Fig. 5b).

\subsection{Cytokine-induced release of cytochrome c from mitochondria and activation of caspase-9 and} -3 in insulin-producing cells 
I. Mehmeti et al.

To characterize the influence of the variant $\mathrm{Bax} / \mathrm{Bcl}-2$ ratios detected in the control, MitoCatalase, and CytoCatalase cells on mitochondrial stability after incubation with IL-1 $\beta$ or the cytokine mixture, the cytokine-induced release of cytochrome $\mathrm{c}$ from mitochondria into the cytosol was studied by Western blot analysis. A $24 \mathrm{~h}$ treatment of control and CytoCatalase overexpressing cells with IL-1 $\beta$ or the cytokine mixture induced an augmented cytochrome $\mathrm{c}$ release into the cytosol (cytokine mixture: $P<0.05$, Fig. 6a). On the other hand, the overexpression of MitoCatalase fully prevented this cytokine-induced cytochrome c release into the cytosol (Fig. 6a). In addition to the cytochrome c release data, the subcellular distribution of the intramitochondrial pro-apoptotic protein, second mitochondria-derived activator of caspase/direct inhibitor of apoptosis-binding protein with low $\mathrm{pI}$ (Smac/DIABLO), a protein that antagonizes the inhibitory effects of the inhibitor of apoptosis protein (IAP) family, in particular of X-linked IAP, was investigated (Fig. 6b). After cytokine treatment, Smac/DIABLO was released into the cytosol in control $(P<0.01)$ and CytoCatalase overexpressing cells (IL-1 $\beta$ : $P<0.05$; cytokine mixture: $P<0.01$ ). The extent of cytokine-mediated Smac/DIABLO release into the cytosol was comparable to the release of cytochrome c. However, in MitoCatalase overexpressing cells, no significant release of Smac/DIABLO from the mitochondria into the cytosol could be detected (Fig. 6b).

Since cytosolic cytochrome $\mathrm{c}$ is part of the apoptosome, executing the processing of procaspase- 9 to activated caspase- 9 , the activity of this caspase was quantified in these cell clones. Control cells treated with the indicated cytokines resulted in a significant activation of caspase-9 (IL1ß: $190 \%$, cytokine mixture: $208 \%$ compared with untreated cells, $P<0.01)$. This cytokine-mediated activation of caspase-9 was also observed in CytoCatalase overexpressing cells (IL-1 $\beta$ : 235\% ( $P$ <0.05), cytokine mixture: $271 \%(P<0.01)$ compared with untreated cells $)$. Nonetheless, the overexpression of MitoCatalase suppressed this cytokine-mediated caspase-9 activation nearly completely (IL-1ß: 127\%, cytokine mixture: 120\% compared with untreated cells, Fig. 7a). In addition, the cytokine-induced activation of the executioner caspase- 3 was assessed as a characteristic hallmark of apoptotic cell death. As shown in Fig. 7b the exposure of control cells to IL-1 $\beta$ alone or the cytokine mixture resulted in a significant activation of caspase-3 (IL-1 $\beta$ : 213\%, cytokine mixture: $202 \%$ compared with untreated cells, $P<0.05)$. CytoCatalase overexpressing cells showed also 
I. Mehmeti et al.

increased caspase-3 activation after cytokine treatment. However, only cells treated with the cytokine mixture exhibited a statistically significant activation of caspase-3 (IL-1 $\beta$ : 158\%, cytokine mixture: 179\% ( $P<0.05)$ compared with untreated cells). In accordance with the prevention of caspase-9 activation in MitoCatalase cells, cytokine-induced caspase-3 activation was also completely abolished by MitoCatalase (IL-1 : 98\%, cytokine mixture: 104\% compared with untreated cells, Fig. 7b).

Taken together, these results on cytochrome c release and caspase-9 activation indicate mitochondria are a major target of pro-inflammatory cytokines finally leading to caspase-3 activation and induction of apoptosis. Prevention of this intrinsic apoptosis pathway by MitoCatalase overexpression suggests mitochondrially generated $\mathrm{H}_{2} \mathrm{O}_{2}$ is involved in this process. 


\section{Mehmeti et al.}

\section{Discussion}

In the present study we show that the pro-apoptotic protein Bax is expressed at significantly higher levels than the anti-apoptotic protein Bcl-2, in both primary rat islets and insulin-producing RINm5F cells. Exposure to cytotoxic cytokines strongly increased the Bax/Bcl-2 ratio in favor of the pro-apoptotic Bax protein. However, overexpression of mitochondrially located $\mathrm{H}_{2} \mathrm{O}_{2}$ detoxifying catalase (MitoCatalase) decreased the Bax expression and increased expression of Bcl-2 in insulinproducing cells. In addition, cells overexpressing MitoCatalase prevented the cytokine-induced release of the mitochondrial pro-apoptotic factors cytochrome $\mathrm{c}$ and Smac/DIABLO and consequently the activation of caspase- 9 and the downstream executioner caspase-3. Taken together, these data indicate that ROS-mediated loss of mitochondrial integrity and an increased Bax/Bcl-2 ratio are crucial for cytokine-induced beta cell apoptosis.

Previously, it was suggested that Bcl-2 family members are key regulators of apoptosis and that the stoichiometry of pro- and anti-apoptotic molecules decides the fate of the cell (Youle and Strasser, 2008). High Bax activity, induced through various apoptotic stimuli, has been considered a critical event in the process of beta cell apoptosis (Grunnet et al., 2009; Tonnesen et al., 2009). Interestingly, in the present study the pro-apoptotic protein Bax showed the highest expression level of all investigated Bcl-2-related proteins in primary rat islets and insulin-producing RINm5F cells; whereas its antagonist Bcl-2 showed the lowest expression. This imbalance between pro- and antiapoptotic proteins contributes to the particular vulnerability of insulin-producing cells to apoptosis. These results are consistent with previous studies performed on isolated human islets, showing that Bax is hyperexpressed compared with Bcl-2; it was postulated that this high Bax expression was caused by the stressful islet isolation procedure (Thomas et al., 2002). However, our findings in both insulin-producing tissue culture cells and isolated primary rat islets strongly suggest that this imbalance is a characteristic of pancreatic beta cells and can be further enhanced by pro-apoptotic stimuli.

Exposure of pancreatic beta cells to pro-inflammatory cytokines has been previously shown to modulate the expression of Bcl-2 family members. In particular, Bcl-2 expression was down-regulated in mouse and human pancreatic islets upon cytokine exposure (Piro et al., 2001; Trincavelli et al., 


\section{Mehmeti et al.}

2002; Van de Casteele et al., 2002); whereas, overexpression of Bcl-2 protected beta cells against cytokine-mediated cell death (Barbu et al., 2002; Rabinovitch et al., 1999; Tran et al., 2003). In the present study with primary islets and insulin-producing RINm5F cells, Bcl-2 expression was also significantly decreased upon exposure to IL-1 $\beta$ and a cytokine mixture, whereas the expression of Bax remained unchanged. This cytokine-mediated modulation of Bcl-2 expression resulted in a markedly elevated Bax/Bcl-2 ratio, which may determine the apoptotic potential of primary islets and RINm5F cells under stress conditions.

Pro-inflammatory cytokines induced expression of the BH3-only proteins Bim and Bid and activated Bad, through $\operatorname{Ser}^{136}$ dephosphorylation, in primary rat islets and insulin-producing RINm5F cells. Bim gene and protein expression were shown to be inducible especially by ER stress inducing compounds, such as thapsigargin. Interestingly, the Bim induction was more profound on the protein than on the mRNA level, possibly due to post-translational modifications resulting in higher protein stability (Puthalakath et al., 2007). In agrement with this study, in primary rat islets and RINm5F cells, Bim protein expression was more pronounced than gene expression in response to cytokines, suggesting that ER stress is also triggered by the cytokines, as previously shown (Eizirik et al., 2008). Bid, proteolytically cleaved by death receptor-activated caspase- 8 , and calcineurin-mediated Bad Ser $^{136}$ dephosphorylation have been considered to be required for beta cell apoptosis (Grunnet et al., 2009; McKenzie et al., 2008). These BH3-only proteins antagonize not only the anti-apoptotic activity of Bcl-2 and Bcl- $\mathrm{X}_{\mathrm{L}}$, but Bid and Bim can also bind Bax with high affinity, thereby inducing its conformational change and translocation to mitochondria (Strasser, 2005; Youle and Strasser, 2008). This results in an amplification of the caspase cascade through engagement of the intrinsic apoptosis pathway. However, neither CytoCatalase nor MitoCatalase had significant effects on basal or cytokine-induced Bim, Bid, and Bad expression, indicating that the detoxification of $\mathrm{H}_{2} \mathrm{O}_{2}$ in both cellular compartments is not involved in BH3-only protein regulation. Despite cytokine-mediated activation of BH3-only proteins in all cell clones, the MitoCatalase cells prevented the cytokineinduced beta cell apoptosis, most likely through decreasing Bax and increasing Bcl-2 expression.

The expression of Bcl-2-related proteins is precisely regulated on the transcriptional and posttranslational level and modified by various stimuli including ROS. Studies with non-insulin-secreting 


\section{Mehmeti et al.}

cells suggested that ROS, in particular $\mathrm{H}_{2} \mathrm{O}_{2}$, decrease the expression of $\mathrm{Bcl}-2$ and increase that of proapoptotic proteins, e.g. Bax (Korsmeyer et al., 1993; Oltvai et al., 1993; Raisova et al., 2001). On the other hand, the reduction of oxidative stress by ROS scavengers and $\mathrm{H}_{2} \mathrm{O}_{2}$ inactivating enzymes could prevent down-regulation of $\mathrm{Bcl}-2$ expression, resulting in higher resistance to apoptotic stimuli in other cell types (Faucher et al., 2005; Hildeman et al., 2003; Pugazhenthi et al., 2003; Wang et al., 2008). While beta cells and insulin-producing cell lines show a moderate even though overall appropriate expression of the superoxide-radical-inactivating enzyme in mitochondria, the $\mathrm{H}_{2} \mathrm{O}_{2}$ inactivating capacity is extremely low compared with other tissues (Lenzen et al., 1996; Tiedge et al., 1997; Lortz et al., 2005). This imbalance is further accentuated by the cytokine-induced expression of MnSOD leading to an aggravation of an already limited antioxidative defense capacity. Thus, these cells highly efficiently dismutate superoxide radicals, but they are prone to accumulate $\mathrm{H}_{2} \mathrm{O}_{2}$ and exhibit a high susceptibility to ROS, especially under inflammatory conditions (Lenzen, 2008). Quantification of intracellular $\mathrm{H}_{2} \mathrm{O}_{2}$ formation in insulin-producing RINm5F cells exposed to proinflammatory cytokines by using the specific $\mathrm{H}_{2} \mathrm{O}_{2}$ sensor HyPer revealed a significant accumulation of $\mathrm{H}_{2} \mathrm{O}_{2}$ within the mitochondria (Lenzen et al., 2009). ROS dissipation through overexpression of catalase resulted in an increased resistance against chemical ROS donors and also cytokine-induced toxicity of these cells. Importantly, catalase overexpression did not affect typical cytokine signaling events such as NFKB activation and iNOS induction (Gurgul et al., 2004; Lortz et al., 2000). ROS formation, induced by pro-inflammatory cytokines, primarily targets mitochondria, causing beta cell damage and death (Lenzen, 2008).

Overexpression of MitoCatalase prevented mitochondrial $\mathrm{H}_{2} \mathrm{O}_{2}$ accumulation (Lenzen et al., 2009) and completely abolished the cytokine-mediated down-regulation of Bcl-2, which resulted in increased basal $\mathrm{Bcl}-2$ and decreased Bax expression. These results are consistent with previous reports showing that overexpression of GPX1 and treatment with the synthetic antioxidant MnTBAP, also mitochondrially located, increased Bcl-2 expression and protected against ROS-mediated Bcl-2 downregulation (Faucher et al., 2005; Orrenius et al., 2007; Wang et al., 2008).

Furthermore, MitoCatalase overexpression successfully suppressed cytokine-mediated release of cytochrome $\mathrm{c}$ and consequently the activation of the caspase cascade, as shown by the inhibition of 


\section{Mehmeti et al.}

caspase- 9 and activation of caspase-3. On the other hand, the overexpression of cytosolically located catalase failed to prevent cytokine-induced Bcl-2 down-regulation, to reverse the imbalanced Bax/Bcl2 ratio, and to suppress the release of mitochondrial apoptotic factors resulting in the caspase cascade activation. However, the cytokine-induced caspase-3 activation was slightly attenuated in these cells, suggesting a possible involvement of cytosolic $\mathrm{H}_{2} \mathrm{O}_{2}$ in cytokine-mediated beta cell death. This is consistent with the earlier observed partial protection against pro-inflammatory cytokine toxicity in CytoCatalase overexpressing cells (Gurgul et al., 2004; Lortz et al., 2000). These findings indicate that $\mathrm{H}_{2} \mathrm{O}_{2}$ of mitochondrial origin induced by pro-inflammatory cytokines is the major oxidative species responsible for Bcl-2 down-regulation and activation of downstream apoptotic events in insulinproducing cells.

Pro-inflammatory cytokines, especially TNF- $\alpha$, are known to increase mitochondrial ROS production in many cell types (Yang et al., 2007). Thus, mitochondrial ROS are crucial for full toxicity of cytokines. The precise mechanism involving mitochondrial ROS signaling in cytokineinduced apoptosis is still unknown, but it has been postulated that the direct damaging effects of mitochondrial ROS include cardiolipin peroxidation, facilitation of mitochondrial permeability transition, and inhibition of mitochondrial metabolism (Orrenius, 2007). Besides these direct damaging effects of mitochondrial ROS, the effects of MitoCatalase overexpression on Bcl-2 gene and protein expression suggest a crosstalk between mitochondrial ROS generation and Bcl-2 expression. The Bcl-2 expression is predominantly regulated by the phosphorylated transcription factor, cAMP response element-binding protein (CREB), which is up-regulated by the PI-3K/Akt pathway and down-regulated by $\mathrm{Ca}^{2+}$ dependent phosphatases, including calcineurin (Pugazhenthi et al., 2000; See and Loeffler, 2001). Bcl-2 promoter activity has been impaired through cytokine-induced downregulation of phosphorylated CREB in MIN6 cells, whereas the overexpression of wild-type CREB protected against cytokine-induced toxicity in these cells (Jambal et al., 2003). Indeed, we also observed a cytokine-induced reduction of CREB dependent Bcl-2 promoter activity in RINm5F cells, which was diminished through overexpression of MitoCatalase (unpublished observation). Thus, it is likely that CREB is the major link between mitochondrial $\mathrm{H}_{2} \mathrm{O}_{2}$ and the decrease in Bcl-2 gene expression in beta cells. Alternatively, as recently reported, Bcl-2 promoter activity can be modulated 
I. Mehmeti et al.

by the p53 pathway (Bourgarel-Rey et al., 2009), which can be initiated by mitochondrial ROS (Niizuma et al., 2009; Soberanes et al., 2006). Further experiments are needed to distinguish the impact of CREB, p53, and possibly other transcription factors on the Bcl-2 promoter level and to determine the influence of mitochondrial ROS on their activity in beta cells.

Overall, the present results show that ROS of mitochondrial origin are major mediators in the regulation of cytokine-induced beta cell apoptosis. Moreover, we showed that MitoCatalase overexpression can compensate for the cytokine-mediated increase of the $\mathrm{Bax} / \mathrm{Bcl}-2$ ratio and prevent cytochrome c release and the activation of caspase-9 and -3 . The efficient detoxification of mitochondrial $\mathrm{H}_{2} \mathrm{O}_{2}$ protects against cytokine-mediated beta cell apoptosis and provides insights into the action of mitochondrial ROS and their redox signaling during beta cell apoptosis. 
I. Mehmeti et al.

\section{Conflict of interest}

The authors declare that they have no conflict of interest.

\section{Acknowledgments}

1.1.1.1.1 We are grateful to Martin Wirth for his skillful technical assistance. This work was supported by the European Union (STREP Savebeta, contract no 036903 in the Framework Program 6 [FP6] of the European Community). 
I. Mehmeti et al.

\section{References}

Adams, J.M., Cory, S., 1998. The Bcl-2 protein family: arbiters of cell survival. Science 281, $1322-1326$.

Atkinson, M.A., 2005. ADA Outstanding Scientific Achievement Lecture 2004. Thirty years of investigating the autoimmune basis for type 1 diabetes: why can't we prevent or reverse this disease? Diabetes 54, 1253-1263.

Barbu, A., Welsh, N., Saldeen, J., 2002. Cytokine-induced apoptosis and necrosis are preceded by disruption of the mitochondrial membrane potential (Deltapsi(m)) in pancreatic RINm5F cells: prevention by Bcl-2. Mol Cell Endocrinol 190, 75-82.

Bourgarel-Rey, V., Savry, A., Hua, G., Carre, M., Bressin, C., Chacon, C., Imbert, J., Braguer, D., Barra, Y., 2009. Transcriptional down-regulation of Bcl-2 by vinorelbine: identification of a novel binding site of p53 on Bcl-2 promoter. Biochem Pharmacol $78,1148-1156$.

Danial, N.N., Korsmeyer, S.J., 2004. Cell death: critical control points. Cell 116, 205-219.

Eizirik, D.L., Cardozo, A.K., Cnop, M., 2008. The role for endoplasmic reticulum stress in diabetes mellitus. Endocr Rev 29, 42-61.

Eizirik, D.L., Mandrup-Poulsen, T., 2001. A choice of death--the signal-transduction of immune-mediated beta-cell apoptosis. Diabetologia 44, 2115-2133.

Faucher, K., Rabinovitch-Chable, H., Cook-Moreau, J., Barriere, G., Sturtz, F., Rigaud, M., 2005. Overexpression of human GPX1 modifies Bax to Bcl-2 apoptotic ratio in human endothelial cells. Mol Cell Biochem 277, 81-87.

Grunnet, L.G., Aikin, R., Tonnesen, M.F., Paraskevas, S., Blaabjerg, L., Storling, J., Rosenberg, L., Billestrup, N., Maysinger, D., Mandrup-Poulsen, T., 2009. Proinflammatory cytokines activate the intrinsic apoptotic pathway in beta-cells. Diabetes 58, 1807-1815.

Gurgul, E., Lortz, S., Tiedge, M., Jörns, A., Lenzen, S., 2004. Mitochondrial catalase overexpression protects insulin-producing cells against toxicity of reactive oxygen species and proinflammatory cytokines. Diabetes 53, 2271-2280.

Hildeman, D.A., Mitchell, T., Aronow, B., Wojciechowski, S., Kappler, J., Marrack, P., 2003. Control of Bcl-2 expression by reactive oxygen species. Proc Natl Acad Sci U S A 100, 15035-15040.

Huerta, S., Goulet, E.J., Huerta-Yepez, S., Livingston, E.H., 2007. Screening and detection of apoptosis. J Surg Res 139, 143-156.

Jambal, P., Masterson, S., Nesterova, A., Bouchard, R., Bergman, B., Hutton, J.C., Boxer, L.M., Reusch, J.E., Pugazhenthi, S., 2003. Cytokine-mediated down-regulation of the transcription factor cAMP-response element-binding protein in pancreatic beta-cells. J Biol Chem 278, 23055-23065.

Kim, K.A., Lee, M.S., 2009. Recent progress in research on beta-cell apoptosis by cytokines. Front Biosci 14, 657-664.

Korsmeyer, S.J., Shutter, J.R., Veis, D.J., Merry, D.E., Oltvai, Z.N., 1993. Bcl-2/Bax: a rheostat that regulates an anti-oxidant pathway and cell death. Semin Cancer Biol 4, 327-332.

Kroemer, G., Galluzzi, L., Brenner, C., 2007. Mitochondrial membrane permeabilization in cell death. Physiol Rev 87, 99-163.

Lenzen, S., 2008. Oxidative stress: the vulnerable beta-cell. Biochem Soc Trans 36, 343-347.

Lenzen, S., Drinkgern, J., Tiedge, M., 1996. Low antioxidant enzyme gene expression in pancreatic islets compared with various other mouse tissues. Free Radic Biol Med 20, 463-466.

Lenzen, S., Lortz, S., Gurgul-Convey, E., 2009. Nitrooxidative stress as a mechanism of cytokine-mediated toxicity in insulin-producing cells. Diabetologia 52 Suppl 1, S150. 
I. Mehmeti et al.

Lenzen, S., Schmidt, W., Panten, U., 1985. Transamination of neutral amino acids and 2-keto acids in pancreatic B-cell mitochondria. J Biol Chem 260, 12629-12634.

Lortz, S., Gurgul-Convey, E., Lenzen, S., Tiedge, M., 2005. Importance of mitochondrial superoxide dismutase expression in insulin-producing cells for the toxicity of reactive oxygen species and proinflammatory cytokines. Diabetologia 48, 1541-1548.

Lortz, S., Tiedge, M., Nachtwey, T., Karlsen, A.E., Nerup, J., Lenzen, S., 2000. Protection of insulin-producing RINm5F cells against cytokine-mediated toxicity through overexpression of antioxidant enzymes. Diabetes 49, 1123-1130.

McKenzie, M.D., Carrington, E.M., Kaufmann, T., Strasser, A., Huang, D.C., Kay, T.W., Allison, J., Thomas, H.E., 2008. Proapoptotic BH3-only protein Bid is essential for death receptor-induced apoptosis of pancreatic beta-cells. Diabetes 57, 1284-1292.

Millan, A., Huerta, S., 2009. Apoptosis-inducing factor and colon cancer. J Surg Res 151, 163-170.

Nerup, J., Mandrup-Poulsen, T., Helqvist, S., Andersen, H.U., Pociot, F., Reimers, J.I., Cuartero, B.G., Karlsen, A.E., Bjerre, U., Lorenzen, T., 1994. On the pathogenesis of IDDM. Diabetologia 37 Suppl 2, S82-89.

Nielsen, K., Kruhoffer, M., Orntoft, T., Sparre, T., Wang, H., Wollheim, C., Jorgensen, M.C., Nerup, J., Karlsen, A.E., 2004. Gene expression profiles during beta cell maturation and after IL-1beta exposure reveal important roles of Pdx-1 and Nkx6.1 for IL-1beta sensitivity. Diabetologia 47, 2185-2199.

Niizuma, K., Endo, H., Chan, P.H., 2009. Oxidative stress and mitochondrial dysfunction as determinants of ischemic neuronal death and survival. J Neurochem 109 Suppl 1, 133138.

Oltvai, Z.N., Milliman, C.L., Korsmeyer, S.J., 1993. Bcl-2 heterodimerizes in vivo with a conserved homolog, Bax, that accelerates programmed cell death. Cell 74, 609-619.

Orrenius, S., 2007. Reactive oxygen species in mitochondria-mediated cell death. Drug Metab Rev 39, 443-455.

Orrenius, S., Gogvadze, V., Zhivotovsky, B., 2007. Mitochondrial oxidative stress: implications for cell death. Annu Rev Pharmacol Toxicol 47, 143-183.

Piro, S., Lupi, R., Dotta, F., Patane, G., Rabuazzo, M.A., Marselli, L., Santangelo, C., Realacci, M., Del Guerra, S., Purrello, F., Marchetti, P., 2001. Bovine islets are less susceptible than human islets to damage by human cytokines. Transplantation 71, 2126.

Pugazhenthi, S., Nesterova, A., Jambal, P., Audesirk, G., Kern, M., Cabell, L., Eves, E., Rosner, M.R., Boxer, L.M., Reusch, J.E., 2003. Oxidative stress-mediated downregulation of bcl-2 promoter in hippocampal neurons. J Neurochem 84, 982-996.

Pugazhenthi, S., Nesterova, A., Sable, C., Heidenreich, K.A., Boxer, L.M., Heasley, L.E., Reusch, J.E., 2000. Akt/protein kinase B up-regulates Bcl-2 expression through cAMP-response element-binding protein. J Biol Chem 275, 10761-10766.

Puthalakath, H., O'Reilly, L.A., Gunn, P., Lee, L., Kelly, P.N., Huntington, N.D., Hughes, P.D., Michalak, E.M., McKimm-Breschkin, J., Motoyama, N., Gotoh, T., Akira, S., Bouillet, P., Strasser, A., 2007. ER stress triggers apoptosis by activating BH3-only protein Bim. Cell 129, 1337-1349.

Rabinovitch, A., Suarez-Pinzon, W., Strynadka, K., Ju, Q., Edelstein, D., Brownlee, M., Korbutt, G.S., Rajotte, R.V., 1999. Transfection of human pancreatic islets with an anti-apoptotic gene (bcl-2) protects beta-cells from cytokine-induced destruction. Diabetes 48, 1223-1229.

Raisova, M., Hossini, A.M., Eberle, J., Riebeling, C., Wieder, T., Sturm, I., Daniel, P.T., Orfanos, C.E., Geilen, C.C., 2001. The Bax/Bcl-2 ratio determines the susceptibility of human melanoma cells to CD95/Fas-mediated apoptosis. J Invest Dermatol 117, 333 340 . 
I. Mehmeti et al.

Sawada, M., Sun, W., Hayes, P., Leskov, K., Boothman, D.A., Matsuyama, S., 2003. Ku70 suppresses the apoptotic translocation of Bax to mitochondria. Nat Cell Biol 5, 320329.

See, V., Loeffler, J.P., 2001. Oxidative stress induces neuronal death by recruiting a protease and phosphatase-gated mechanism. J Biol Chem 276, 35049-35059.

Soberanes, S., Panduri, V., Mutlu, G.M., Ghio, A., Bundinger, G.R., Kamp, D.W., 2006. p53 mediates particulate matter-induced alveolar epithelial cell mitochondria-regulated apoptosis. Am J Respir Crit Care Med 174, 1229-1238.

Souza, K.L., Gurgul-Convey, E., Elsner, M., Lenzen, S., 2008. Interaction between proinflammatory and anti-inflammatory cytokines in insulin-producing cells. J Endocrinol 197, 139-150.

Strasser, A., 2005. The role of BH3-only proteins in the immune system. Nat Rev Immunol 5, 189-200.

Susnow, N., Zeng, L., Margineantu, D., Hockenbery, D.M., 2009. Bcl-2 family proteins as regulators of oxidative stress. Semin Cancer Biol 19, 42-49.

Thomas, D., Yang, H., Boffa, D.J., Ding, R., Sharma, V.K., Lagman, M., Li, B., Hering, B., Mohanakumar, T., Lakey, J., Kapur, S., Hancock, W.W., Suthanthiran, M., 2002. Proapoptotic Bax is hyperexpressed in isolated human islets compared with antiapoptotic Bcl-2. Transplantation 74, 1489-1496.

Tiedge, M., Lortz, S., Drinkgern, J., Lenzen, S., 1997. Relation between antioxidant enzyme gene expression and antioxidative defense status of insulin-producing cells. Diabetes 46, 1733-1742.

Tonnesen, M.F., Grunnet, L.G., Friberg, J., Cardozo, A.K., Billestrup, N., Eizirik, D.L., Størling, J., Mandrup-Poulsen, T., 2009. Inhibition of nuclear factor-kappaB or Bax prevents endoplasmic reticulum stress- but not nitric oxide-mediated apoptosis in INS$1 \mathrm{E}$ cells. Endocrinology 150, 4094-4103.

Tran, V.V., Chen, G., Newgard, C.B., Hohmeier, H.E., 2003. Discrete and complementary mechanisms of protection of beta-cells against cytokine-induced and oxidative damage achieved by bcl-2 overexpression and a cytokine selection strategy. Diabetes $52,1423-1432$.

Trincavelli, M.L., Marselli, L., Falleni, A., Gremigni, V., Ragge, E., Dotta, F., Santangelo, C., Marchetti, P., Lucacchini, A., Martini, C., 2002. Upregulation of mitochondrial peripheral benzodiazepine receptor expression by cytokine-induced damage of human pancreatic islets. J Cell Biochem 84, 636-644.

Van de Casteele, M., Kefas, B.A., Ling, Z., Heimberg, H., Pipeleers, D.G., 2002. Specific expression of Bax-omega in pancreatic beta-cells is down-regulated by cytokines before the onset of apoptosis. Endocrinology 143, 320-326.

Wang, L., Chanvorachote, P., Toledo, D., Stehlik, C., Mercer, R.R., Castranova, V., Rojanasakul, Y., 2008. Peroxide is a key mediator of Bcl-2 down-regulation and apoptosis induction by cisplatin in human lung cancer cells. Mol Pharmacol 73, 119127.

Wong, W.W., Puthalakath, H., 2008. Bcl-2 family proteins: the sentinels of the mitochondrial apoptosis pathway. IUBMB Life 60, 390-397.

Yang, D., Elner, S.G., Bian, Z.M., Till, G.O., Petty, H.R., Elner, V.M., 2007. Proinflammatory cytokines increase reactive oxygen species through mitochondria and NADPH oxidase in cultured RPE cells. Exp Eye Res 85, 462-472.

Youle, R.J., Strasser, A., 2008. The BCL-2 protein family: opposing activities that mediate cell death. Nat Rev Mol Cell Biol 9, 47-59.

Zha, J., Harada, H., Yang, E., Jockel, J., Korsmeyer, S.J., 1996. Serine phosphorylation of death agonist BAD in response to survival factor results in binding to 14-3-3 not BCLX(L). Cell 87, 619-628. 
I. Mehmeti et al.

\section{Figure legends}

Fig. 1. Expression of Bcl-2-related proteins in primary rat islets and insulin-producing RINm5F cells. (a) Gene expression of anti-apoptotic and pro-apoptotic Bcl-2-related proteins in primary rat islets under control conditions. (b) Gene expression of anti-apoptotic and pro-apoptotic Bcl-2-related proteins in insulin-producing RINm5F cells under control conditions. Total RNA was isolated $24 \mathrm{~h}$ after islet isolation or cell seeding and analyzed by qRT-PCR with gene specific primer sets. The relative expression levels were normalized to the housekeeping gene $\beta$-actin. The gene expression of Bcl-2 in each cell type was set as $100 \%$. Depicted values are means \pm SEM, $n=6-8$.

Fig. 2. Effects of pro-inflammatory cytokines on gene and protein expression of Bcl-2-related proteins in primary rat islets and insulin-producing RINm5F cells. (a) and (c) Isolated rat islets and RINm5F cells were incubated under control conditions, with IL-1 $\beta$ (600 units/ml), or with a cytokine mixture (60 units/ml IL-1 $\beta, 185$ units/ml TNF- $\alpha$, and 14 units/ml IFN- $\gamma$ ). After 24 h, RNA was isolated and relative gene expression was analyzed by qRT-PCR and normalized to the housekeeping gene $\beta$-actin. (b) and (d) Isolated rat islets and RINm5F cells were incubated as in (a and c) and protein expression was quantified by Western blot analysis and normalized to the housekeeping protein $\beta$-actin. A representative blot is shown for each Bcl-2 related protein. The expression of each gene or protein under control conditions was set as $100 \%$. Depicted values are means \pm SEM, $n=6-8$ (mRNA expression) or $n=4$ (protein expression). $* P<0.05 ; * * P<0.01$; *** $P$ $<0.001$ vs. untreated cells.

Fig. 3. Effects of cytoplasmic and mitochondrial catalase overexpression on the expression of the anti-apoptotic protein Bcl-2 and the pro-apoptotic protein Bax in insulin-producing RINm5F cells. (a) Gene expression of Bcl-2 and Bax in RINm5F control cells and cells overexpressing catalase in the cytoplasm (CytoCatalase) or in mitochondria (MitoCatalase) under control conditions. Total RNA was isolated $24 \mathrm{~h}$ after cell seeding, qRT-PCR was performed with gene specific primer sets, and the relative expression levels were normalized to the housekeeping gene $\beta$-actin. (b) Protein 


\section{Mehmeti et al.}

expression of Bcl-2 and Bax in RINm5F control cells and cells overexpressing catalase in the cytoplasm (CytoCatalase) or in mitochondria (MitoCatalase) under control conditions was quantified by Western blot analysis and normalized to the housekeeping protein $\beta$-actin. Gene or protein expression of RINm5F control cells was set as $100 \%$. A representative blot is shown for Bcl-2 and Bax protein expression. Depicted values are means \pm SEM, $n=6$ mRNA expression or $n=4$ protein expression. $* P<0.05 ; * * P<0.01 ; * * * P<0.001$ vs. control cells.

Fig. 4. Effects of pro-inflammatory cytokines on Bcl-2 gene and protein expression in insulinproducing RINm5F control cells and cells overexpressing CytoCatalase or MitoCatalase. (a) Gene expression of Bcl-2 in RINm5F control cells and cells overexpressing catalase in the cytoplasm (CytoCatalase) or in mitochondria (MitoCatalase) after incubation under control conditions, with IL-1 $\beta$ (600 units/ml), or with a cytokine mixture (60 units/ml IL-1 $\beta, 185$ units/ml TNF- $\alpha$, and 14 units/ml IFN- $\gamma$ ). Total RNA was isolated after $24 \mathrm{~h}$ incubation, qRT-PCR was performed with a Bcl-2 specific primer set, and the relative expression levels were normalized to the housekeeping gene $\beta$ actin. (b) Cell clones were treated as in (a) and Bcl-2 protein expression was quantified by Western blot analysis and normalized to the housekeeping protein $\beta$-actin. The $\mathrm{Bcl}-2$ gene or protein expression in each cell clone under control conditions was set as 100\%. A representative blot is shown for Bcl-2 protein expression. Depicted values are means \pm SEM, $n=6$ mRNA expression or $n=4$ protein expression. $* * P<0.01 ; * * * P<0.001 v s$. untreated cells.

Fig. 5. Effects of pro-inflammatory cytokines on Bax gene and protein expression in insulinproducing RINm5F control cells and cells overexpressing CytoCatalase or MitoCatalase. (a) Gene expression of Bax in RINm5F control cells and cells overexpressing catalase in the cytoplasm (CytoCatalase) or in mitochondria (MitoCatalase) after incubation under control conditions, with IL-1 $\beta$ (600 units/ml), or with a cytokine mixture (60 units/ml IL-1 $\beta, 185$ units/ml TNF- $\alpha$, and 14 units/ml IFN- $\gamma$ ). Total RNA was isolated after $24 \mathrm{~h}$ incubation, qRT-PCR was performed with a Bax specific primer set, and the relative expression levels were normalized to the housekeeping gene $\beta$ actin. (b) Cell clones were treated as in (a) and Bax protein expression was quantified by Western blot 


\section{Mehmeti et al.}

analysis and normalized to the housekeeping protein $\beta$-actin. The Bax gene or protein expression in each cell clone under control conditions was set as $100 \%$. A representative blot is shown for Bax protein expression. Depicted values are means \pm SEM, $n=6$ mRNA expression or $n=4$ protein expression. $* * P<0.01 v s$. untreated cells.

Fig. 6. Cytokine-induced release of cytochrome $c$ and Smac/DIABLO from mitochondria of insulin-producing RINm5F control cells and cells overexpressing CytoCatalase or MitoCatalase. Western blot analysis of cytochrome c (a) and Smac/DIABLO (b) release of RINm5F control cells and cells overexpressing catalase in the cytoplasm (CytoCatalase) or in mitochondria (MitoCatalase) after $24 \mathrm{~h}$ incubation with IL-1 $\beta$ (600 units/ml) or with a cytokine mixture (60 units/ml IL-1 $\beta, 185$ units/ml TNF- $\alpha$, and 14 units/ml IFN- $\gamma$ ). Thereafter, the cells were lysed and fractionated into cytoplasmic and mitochondrial fractions by differential centrifugation. Samples were separated by SDS-PAGE, followed by immunoblotting. All blots were re-probed using a specific COX IV and $\beta$ actin antibody to ensure correct separation of mitochondrial and cytosolic fractions and ensure correct sample loading. The cytochrome c or Smac/DIABLO content in each cellular fraction of untreated cells was set as $100 \%$. A representative blot of both proteins is shown. Depicted values are means \pm SEM, $n=3 . * P<0.05 ; * * P<0.01 v s$. untreated cells.

Fig. 7. Effects of pro-inflammatory cytokines on caspase-9 and caspase-3 activation in insulinproducing RINm5F control cells and cells overexpressing CytoCatalase or MitoCatalase.

Quantification caspase-9 (a) and caspase-3 (b) activation of RINm5F control cells and cells overexpressing catalase in the cytoplasm (CytoCatalase) or in mitochondria (MitoCatalase) after $24 \mathrm{~h}$ incubation with IL-1 $\beta$ (600 units $/ \mathrm{ml}$ ) or with a cytokine mixture (60 units/ml IL-1 $\beta, 185$ units/ml TNF- $\alpha$, and 14 units/ml IFN- $\gamma$ ). Thereafter the cells were trypsinized, incubated for 45 min with the FAM-LEDH-FMK (caspase-9) or Red-DEVD-FMK (caspase-3), and the intracellular fluorescence intensity was measured by flow cytometry. Results are means \pm SEM, $n=4 . * P<0.05 ; * * P<0.01 v s$. cells incubated under control conditions; ${ }^{\#} P<0.05 ;{ }^{\# \#} P<0.01$; ${ }^{\# \# \#} P<0.001$ MitoCatalase cells vs. RINm5F control and CytoCatalase cells under the same conditions. 
Table. 1

Sequences and amplification parameters for all primers used for quantitative Real Time PCR analysis

\begin{tabular}{|c|c|c|c|c|}
\hline Gene & \multicolumn{2}{|c|}{ Primer sequence } & Product size & Annealing- \\
\hline $\mathrm{Bcl}-2$ & $\begin{array}{l}\text { fw.: } \\
\text { rv.: }\end{array}$ & $\begin{array}{l}\text { ACTTCTCTCGTCGCTACCGTCGC } \\
\text { AGAGCGATGTTGTCCACCAGGG }\end{array}$ & 216 bp & $60{ }^{\circ} \mathrm{C}$ \\
\hline $\mathrm{Bcl}-\mathrm{X}_{\mathrm{L}}$ & $\begin{array}{l}\text { fw.: } \\
\text { rv.: }\end{array}$ & $\begin{array}{l}\text { GAGACCCCCAGTGCCATCAATG } \\
\text { CTCATCGCCAGCCTCTCTCAGC }\end{array}$ & 152 bp & $60{ }^{\circ} \mathrm{C}$ \\
\hline $\mathrm{Bad}$ & $\begin{array}{l}\text { fw.: } \\
\text { rv.: }\end{array}$ & $\begin{array}{l}\text { CCAGAGTTTGAGCCGAGTGAGCA } \\
\text { CTGTTATTGGCTGCCTGTCCCG }\end{array}$ & $151 \mathrm{bp}$ & $60{ }^{\circ} \mathrm{C}$ \\
\hline Bid & & $\begin{array}{l}\text { TCTGAGGTCAGCAATGGCTCAGG } \\
\text { TTCTTCCATGATAGAAGGAGCGGCT }\end{array}$ & $210 \mathrm{bp}$ & $60{ }^{\circ} \mathrm{C}$ \\
\hline Bim & $\begin{array}{l}\text { fw.: } \\
\text { rv.: }\end{array}$ & $\begin{array}{l}\text { CGGCACCCATGAGTTGTGACAA } \\
\text { TGCAAACGCCCTCCTCGTGTA }\end{array}$ & $199 \mathrm{bp}$ & $60{ }^{\circ} \mathrm{C}$ \\
\hline Bax & $\begin{array}{l}\text { fw.: } \\
\text { rv.: }\end{array}$ & $\begin{array}{l}\text { CCAGGACGCATCCACCAAGAAG } \\
\text { CCCAGTTGAAGTTGCCGTCTGC }\end{array}$ & 169 bp & $60{ }^{\circ} \mathrm{C}$ \\
\hline$\beta$-Actin & $\begin{array}{l}\text { fw: } \\
\text { rv: }\end{array}$ & $\begin{array}{l}\text { GAACACGGCATTGTAACCAACTGG } \\
\text { GGCCACACGCAGCTCATTGTA }\end{array}$ & 79 bp & $60{ }^{\circ} \mathrm{C}$ \\
\hline
\end{tabular}


(a)

primary rat islets

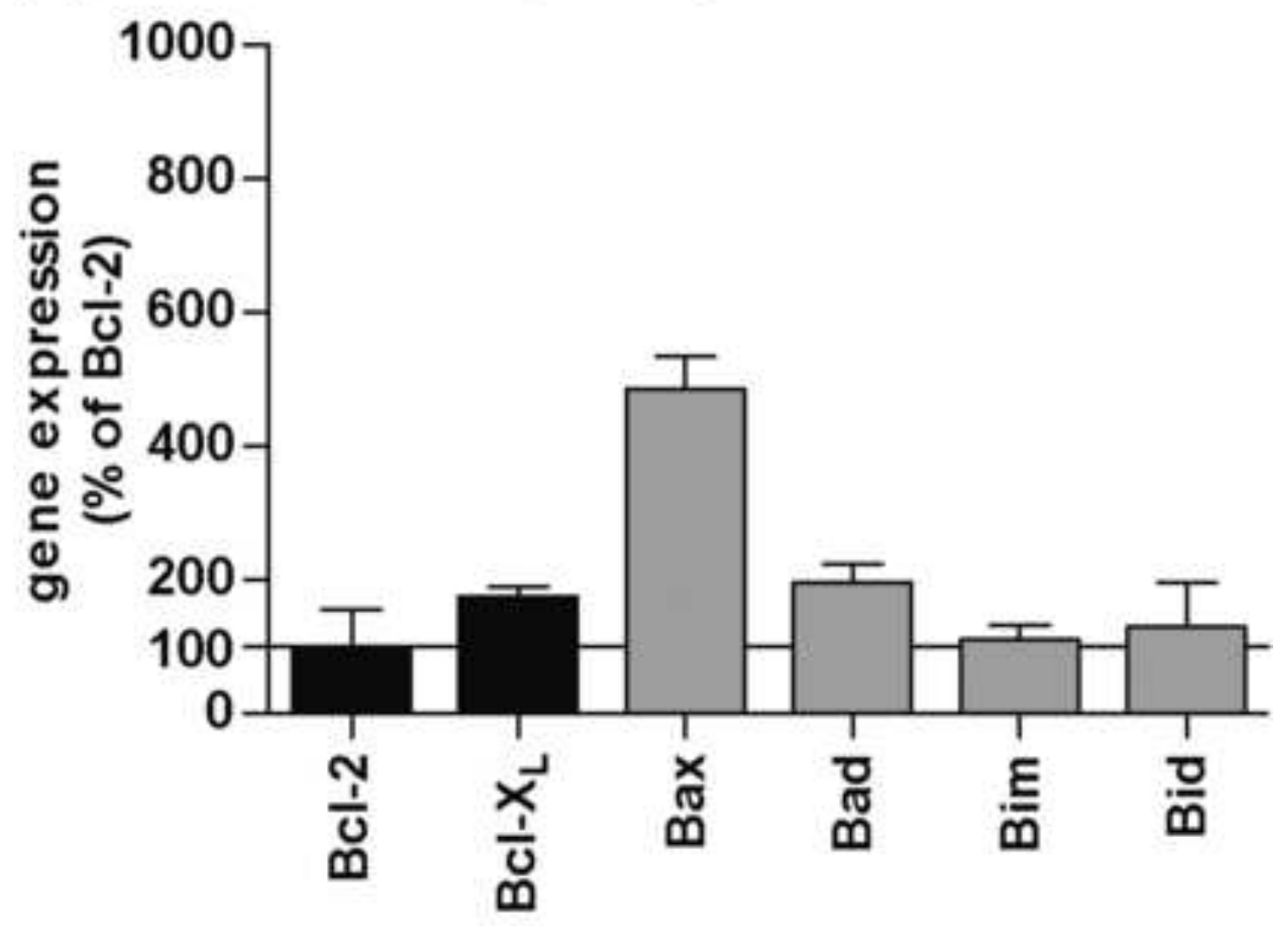

(b)

RINm5F cells

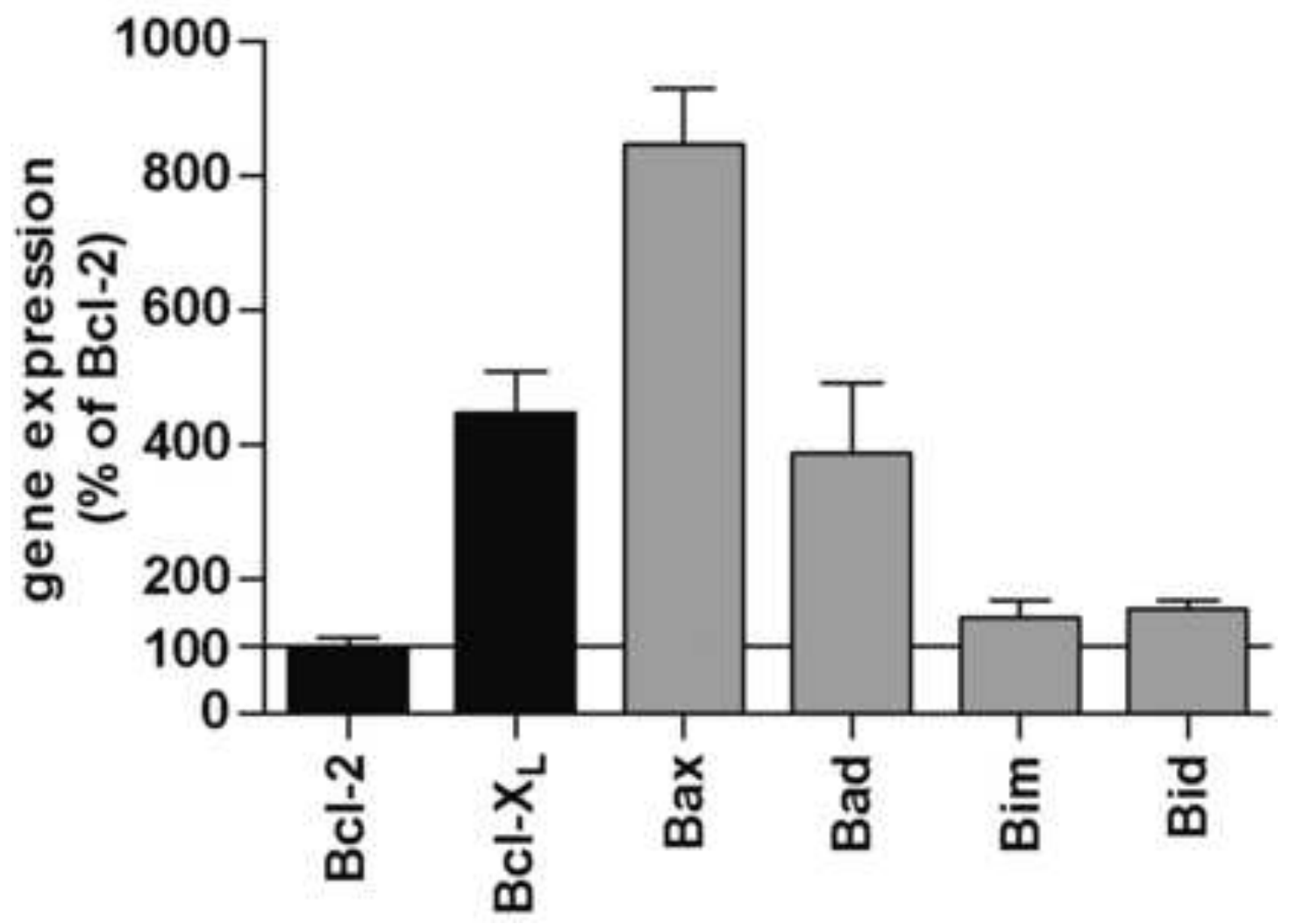


primary rat islets

(a)

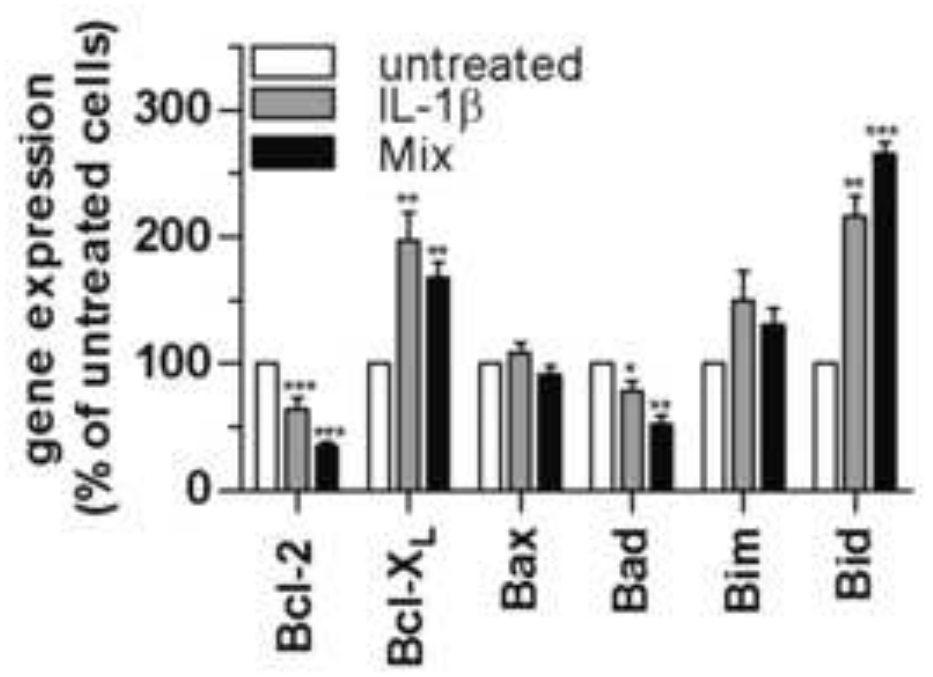

(b)

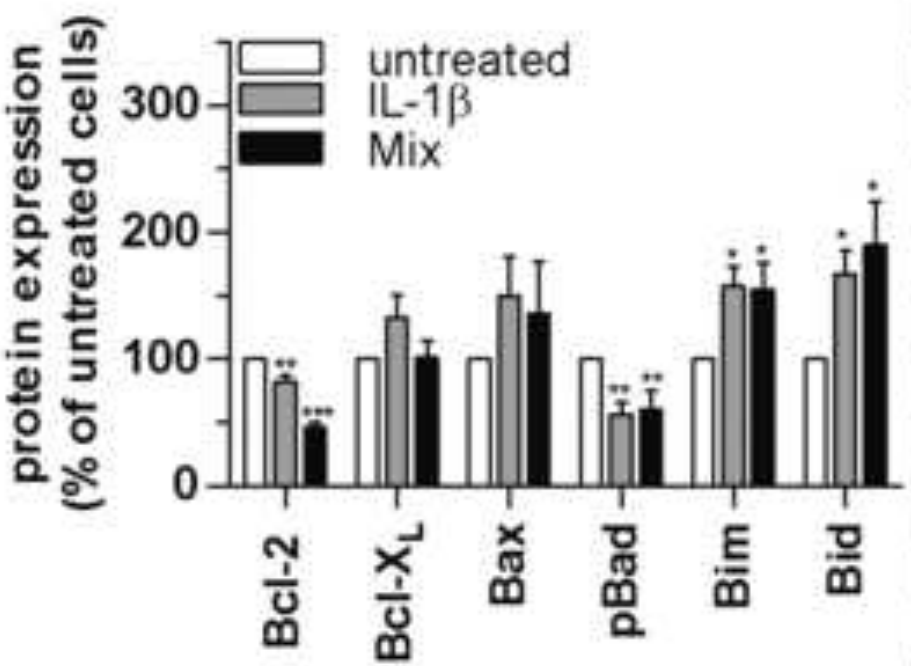

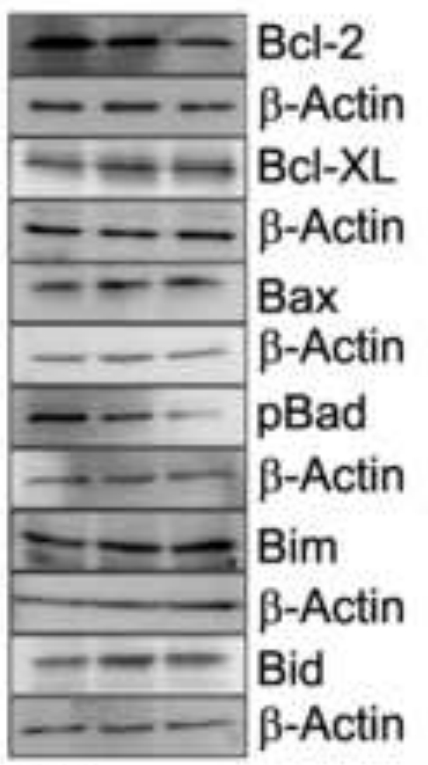

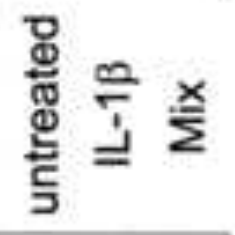

(c)

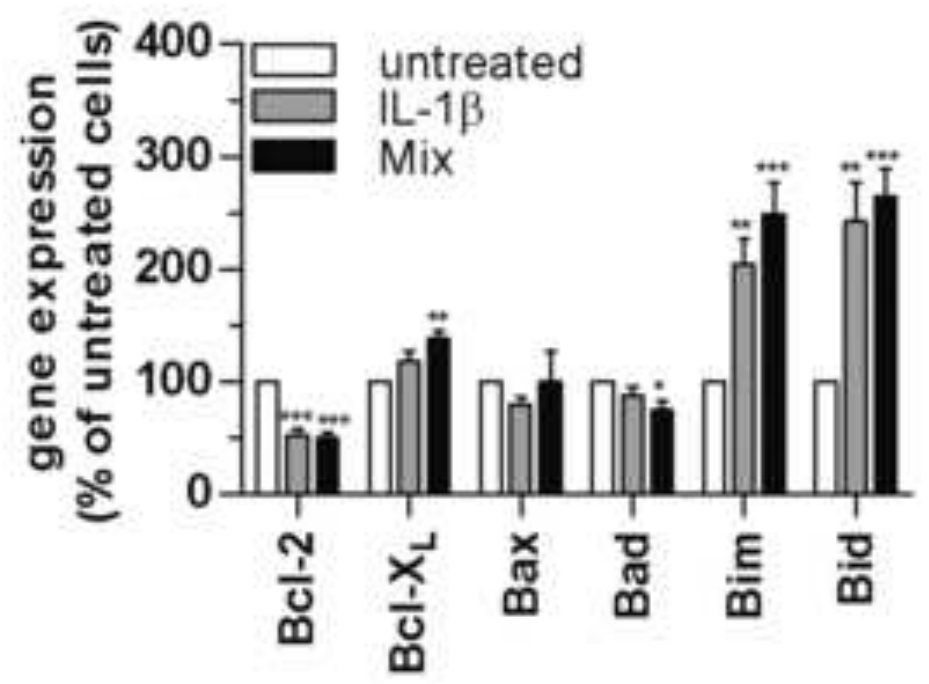

\section{RINm5F cells}

(d)

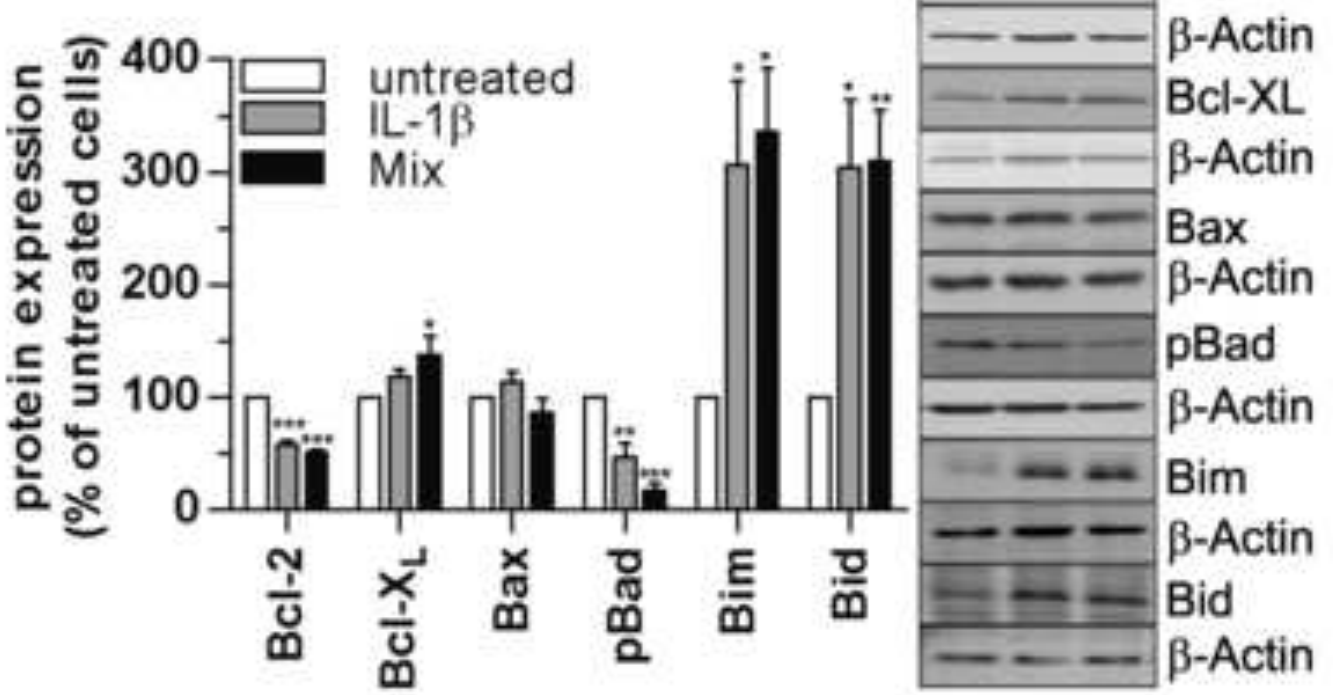


(a)

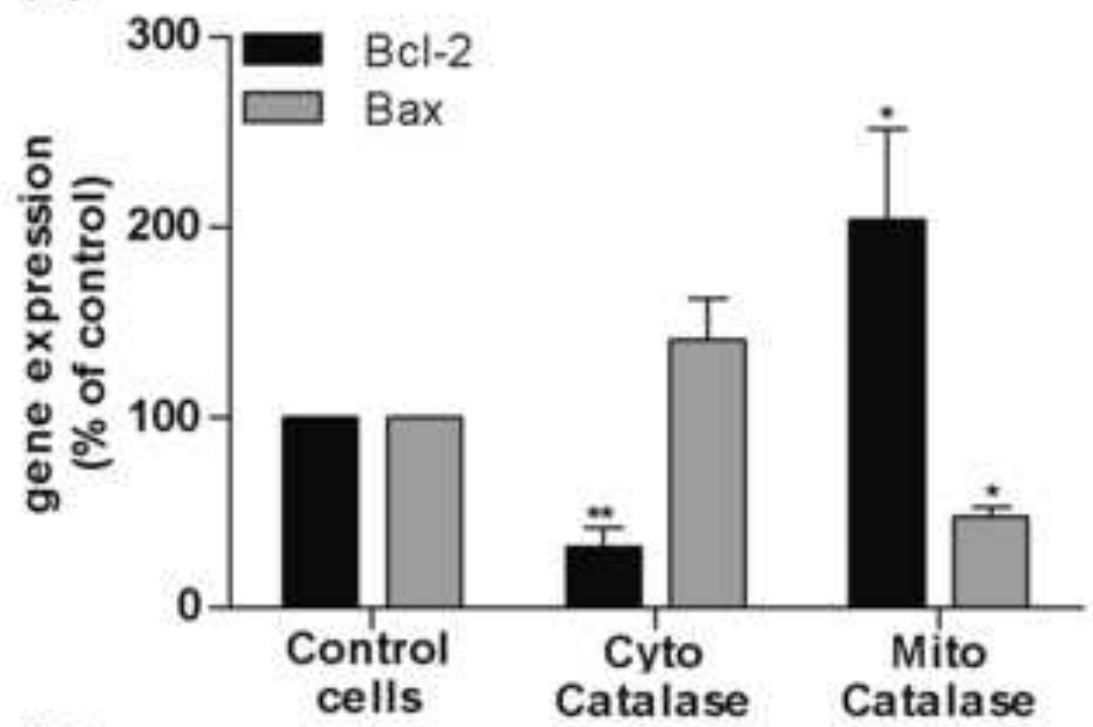

(b)
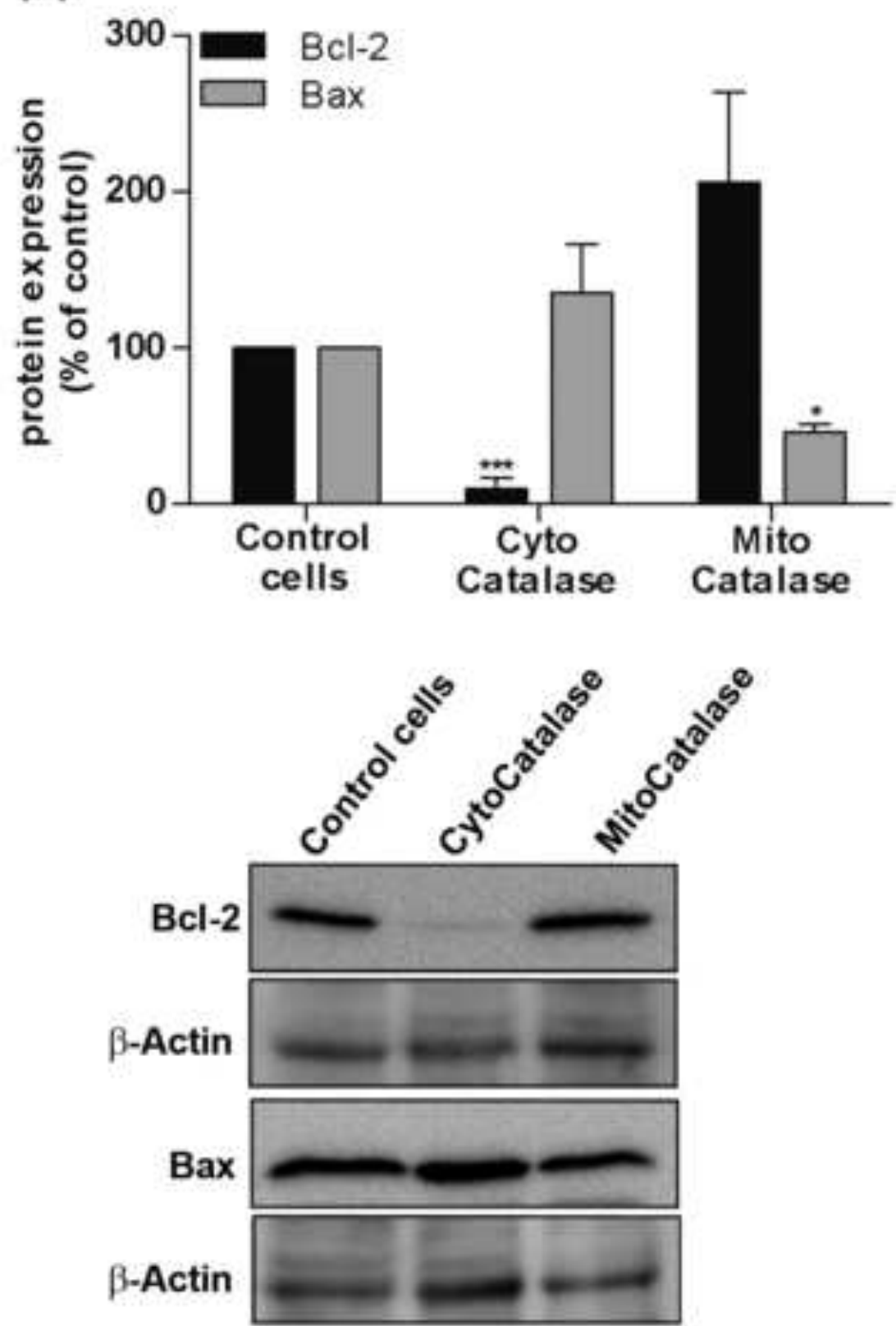

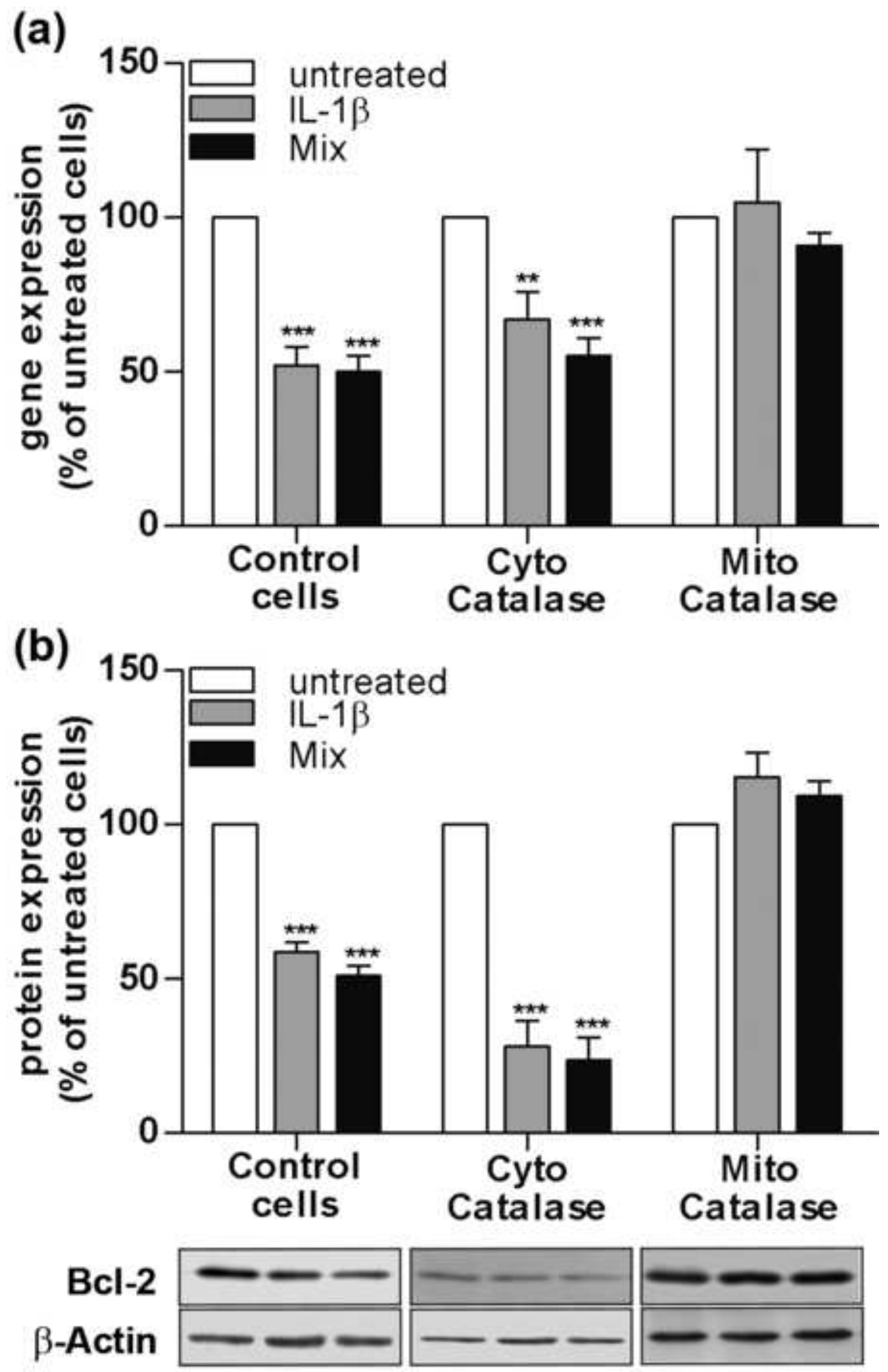


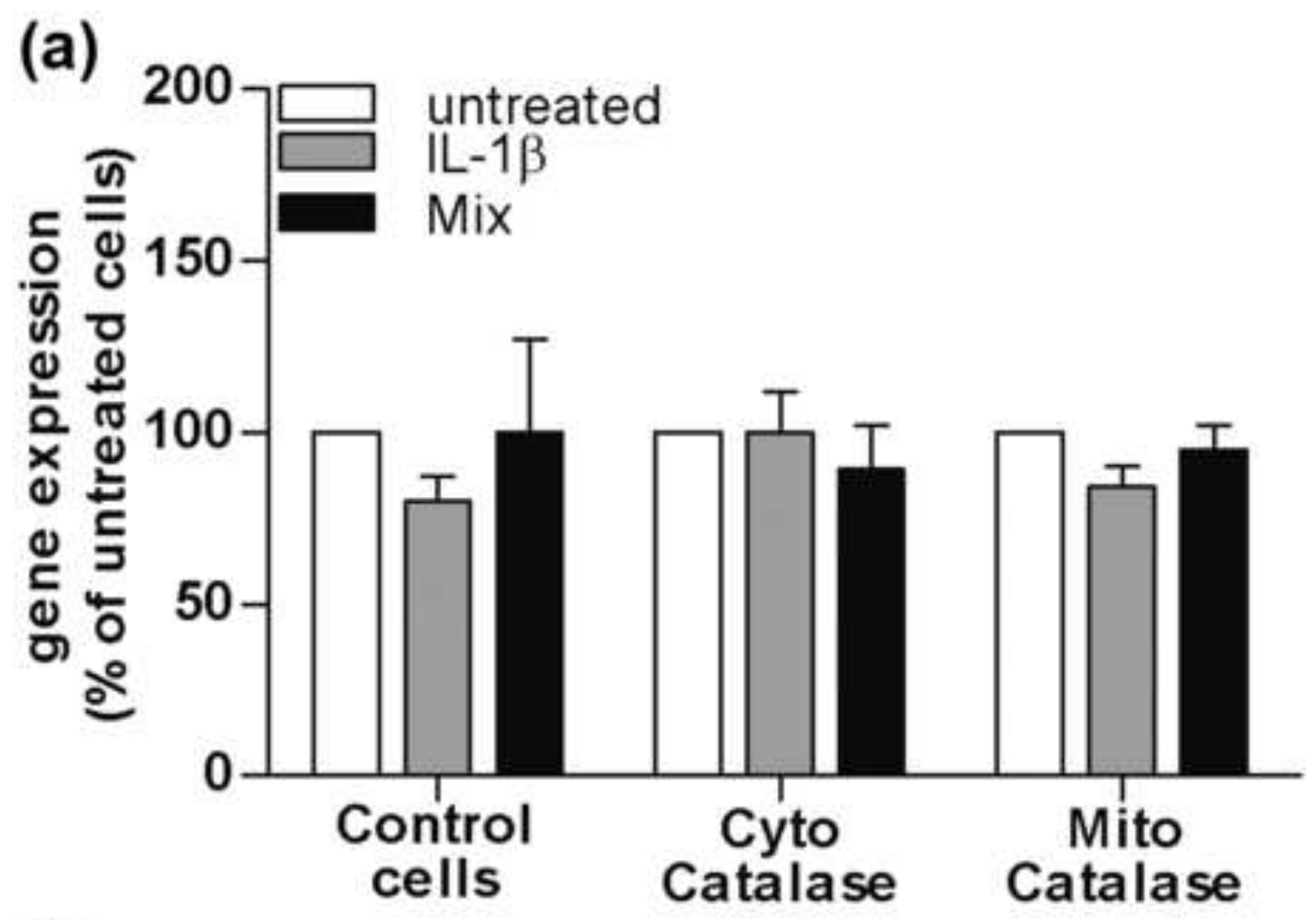

(b)
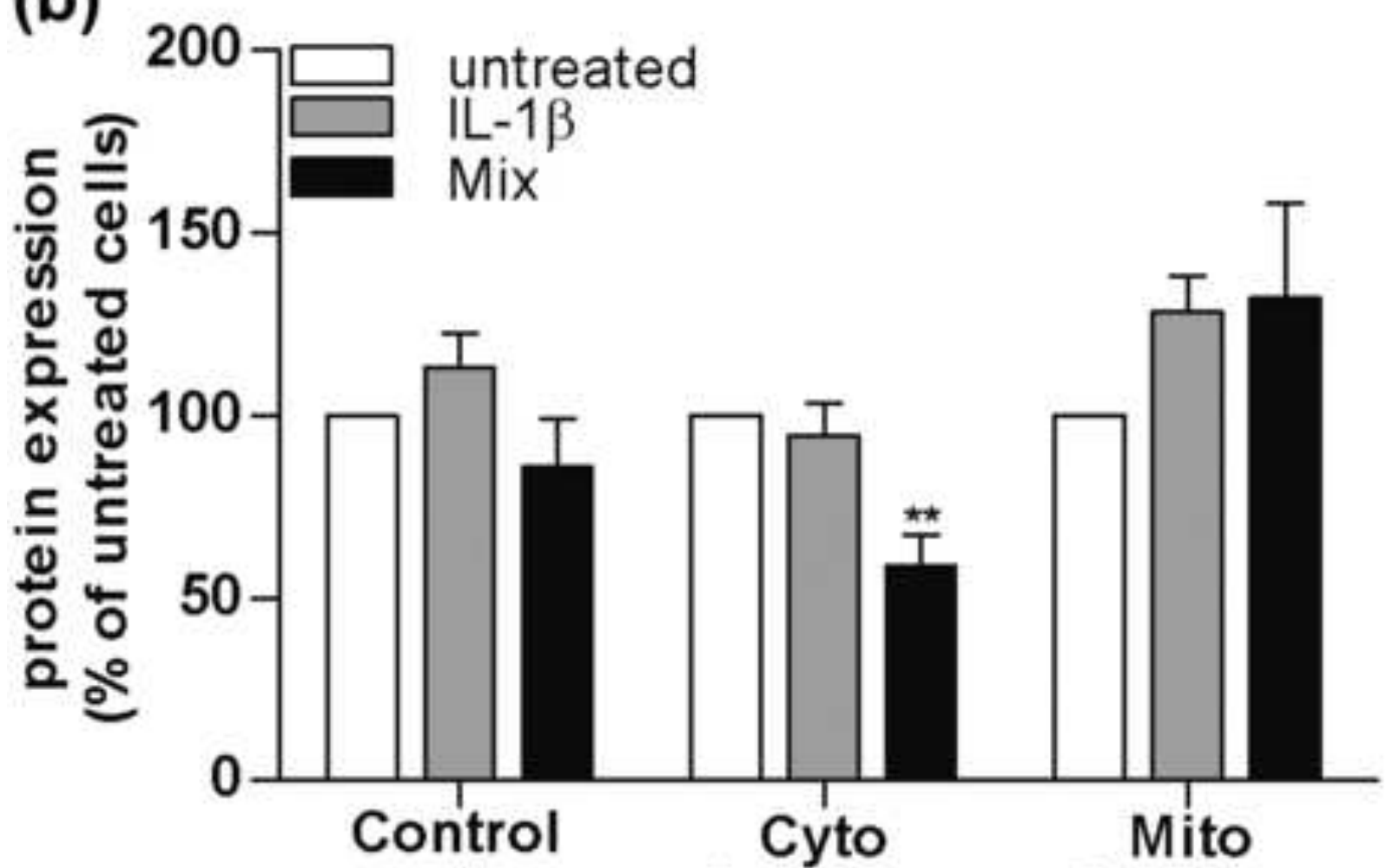
cells

Catalase

Catalase

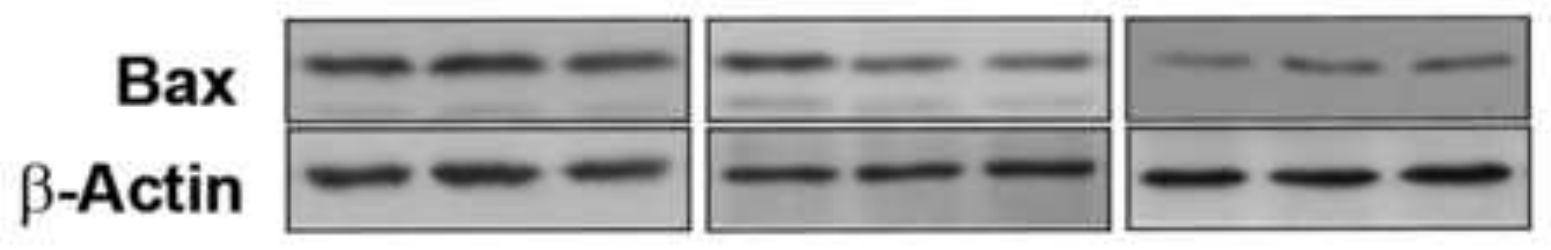


(a)
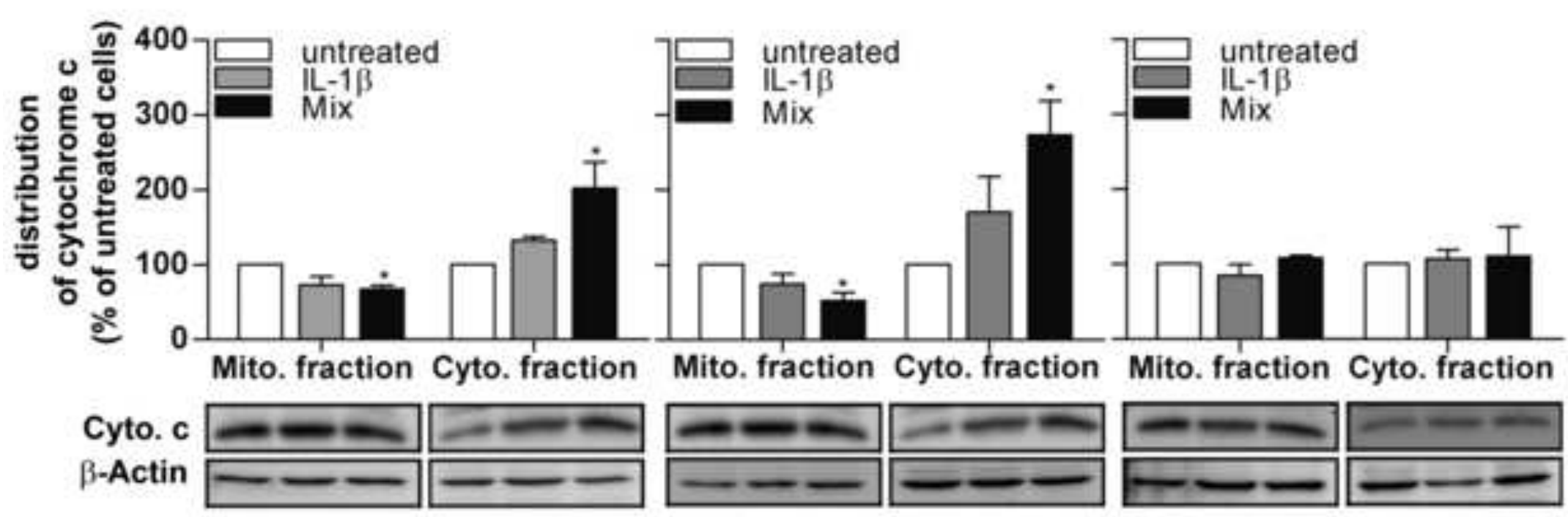

(b)
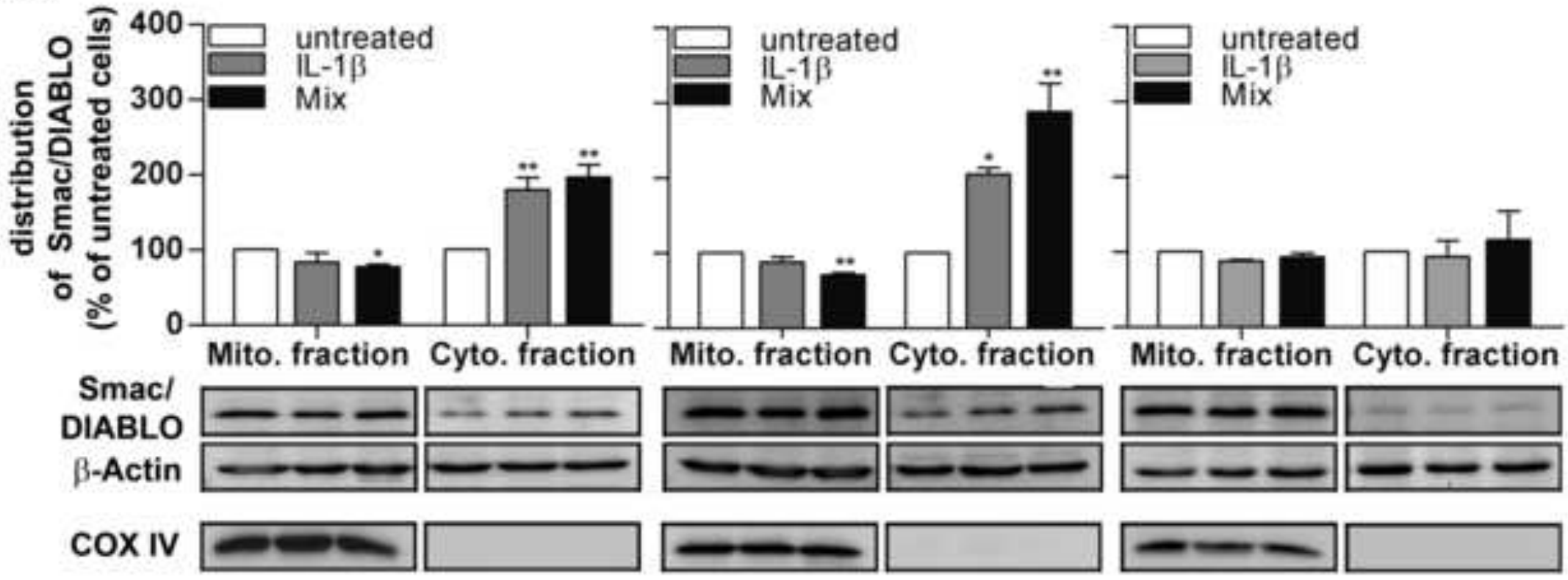

Smacl DIABLO cox IV

IL-1及
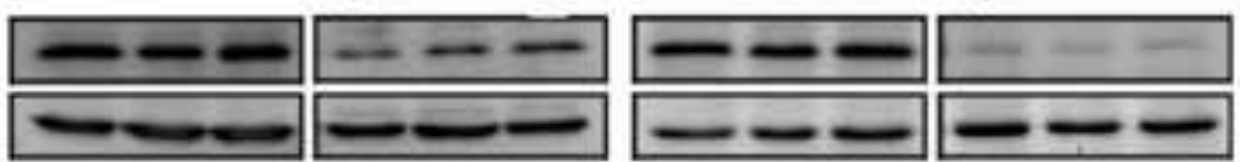

Mix
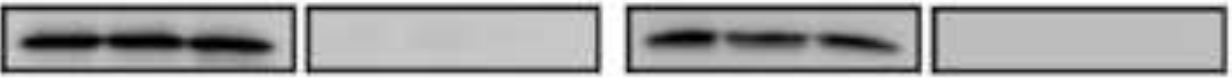

rage 34 or 35 
(a)

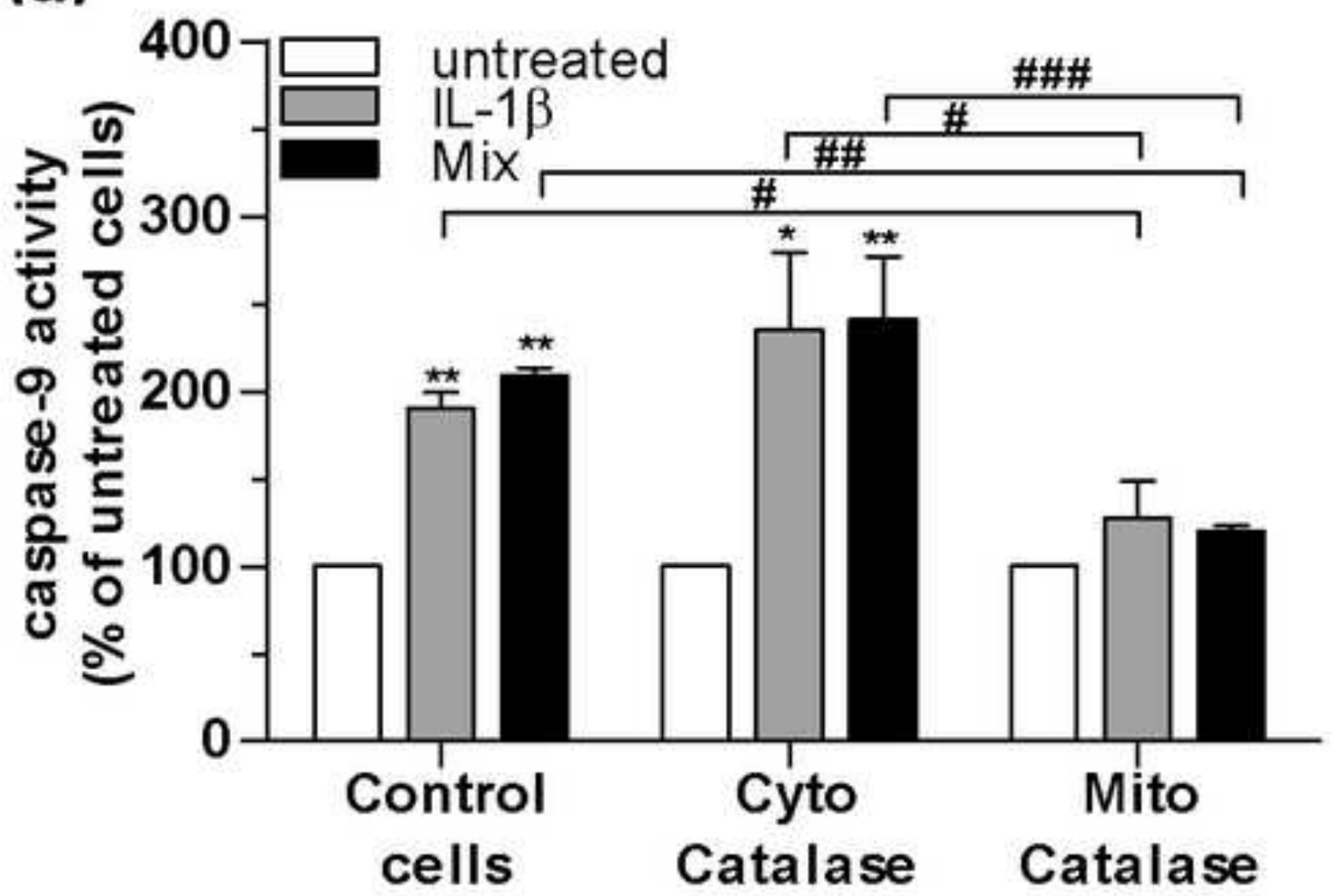

(b)

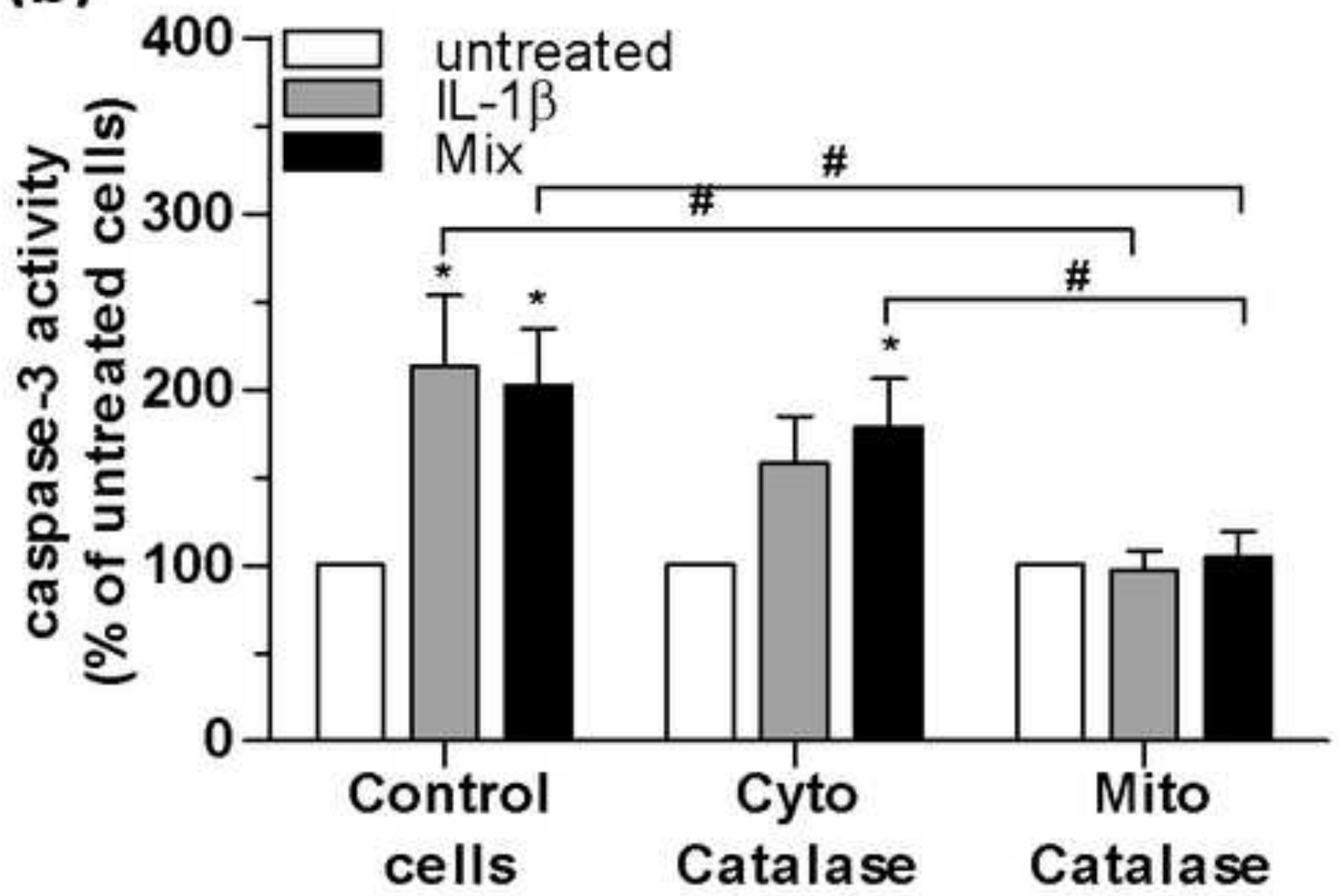

